NBER WORKING PAPER SERIES

\title{
STATE-RUN BANKS, MONEY GROWTH, AND THE REAL ECONOMY
}

\author{
Randall Morck \\ M. Deniz Yavuz \\ Bernard Yeung \\ Working Paper 19004 \\ http://www.nber.org/papers/w19004 \\ NATIONAL BUREAU OF ECONOMIC RESEARCH \\ 1050 Massachusetts Avenue \\ Cambridge, MA 02138 \\ April 2013, Revised February 2018
}

Previously circulated as "State-controlled Banks and the Effectiveness of Monetary Policy." We are very grateful for helpful comments from the associate editor and two anonymous referees, seminar participants at Asian Bureau of Finance and Economics Research, Bank of Canada, the Canadian Economic Association, "Bank of Canada Lecture" in Vancouver, George Washington University, Hebrew University, Monetary Authority of Hong Kong, Monetary Authority of Singapore, National University of Singapore, NBER-EASE in Tokyo, the NBER Summer Institute Capital Markets and the Economy program, Renmin University, Singapore Management University, University of Alberta, Stanford University, University of Oregon, University of Southern California, University of Washington, and for specific comments from Paul Beaudry, Marianne Bertrand, Bernard Black, Robert M. Bushman, Murillo Campello, Zhi Da, Mara Faccio, Ben Friedman, Ross Levine, Greg Mankiw, John Matsusaka, Morten Nielsen, Ali Ozdagli, Amiyatosh Purnanandam, Andrew Rose, Stefano Rossi, Lawrence Schembri, Etsuro Shioji, Andrei Shleifer, Krishnamurthy Subramanian, Chalongphob Sussangkarn, and Jin Xu. We thank William L. Megginson for sharing his privatization data. We thank Timothy Trombley for superb research assistance. Morck gratefully acknowledge funding from the SSHRC and the Bank of Canada. Yavuz gratefully acknowledges support from a CIBER Research Grant. These are the views of the authors and may not reflect those of the Bank of Canada. These are the views of the authors and may not reflect those of the Bank of Canada or the National Bureau of Economic Research.

NBER working papers are circulated for discussion and comment purposes. They have not been peer-reviewed or been subject to the review by the NBER Board of Directors that accompanies official NBER publications.

(C) 2013 by Randall Morck, M. Deniz Yavuz, and Bernard Yeung. All rights reserved. Short sections of text, not to exceed two paragraphs, may be quoted without explicit permission provided that full credit, including $(\odot$ notice, is given to the source. 
State-run Banks, Money Growth, and the Real Economy

Randall Morck, M. Deniz Yavuz, and Bernard Yeung

NBER Working Paper No. 19004

April 2013, Revised February 2018

JEL No. E5,G1,G21,G28,G3,O16,P5

\begin{abstract}
Within countries, state-run banks' lending correlates with prior money growth; otherwise similar private-sector banks' lending does not. Aggregate credit and investment growth correlate with prior money growth more where banking systems are more state-run. Size and liquidity differences between state-run and private-sector banks do not drive these results; further tests discount broad classes of alternative explanations. Tests exploiting heterogeneity in likely political pressure on state-run banks associated with privatizations and elections suggest a command-and-control pseudo-monetary policy channel: changes in money growth, perhaps reflecting political pressure on the central bank, change banks' lending constraints; political pressure actually changes state-run banks' lending.

Randall Morck

Faculty of Business

University of Alberta

Edmonton, AB T6G 2R6

CANADA

and NBER

randall.morck@ualberta.ca

Bernard Yeung

National University of Singapore

Mochtar Riady Building

15 Kent Ridge Drive

BIZ 1, Level 6, \#6-19

Singapore 119245

bizdean@nus.edu.sg

M. Deniz Yavuz

Krannert Graduate School of Management

Purdue University

403 W. State Street

West Lafayette, IN 47907-2056

myavuz@purdue.edu
\end{abstract}




\section{Introduction}

Until recently, macroeconomics impugned money growth as a policy variable for stimulating economic growth, as opposed to targeting inflation (Goodfriend 2007; Mishkin 2011). Nonetheless, policy-makers often countered economic downturns by increasing monetary growth hoping to spur real growth, at least in the short-run, in part by encouraging more bank lending and hence more capital spending, both before (Rasche and Williams 2007) and especially after the 2008 crisis (Mishkin 2009, 2011; Caballero 2010; Claessens et al. 2010; Bernanke 2012). Outcomes are mixed. Bouis et al. (2013) conclude that "monetary policy stimulus did not show up in stronger growth" in OECD economies. In contrast, China's 2008 monetary expansion coincides neatly with lending and investment upturns. Deng et al. (2011) show that China's staterun commercial banks increased lending in response to a monetary stimulus because their top managers were ordered to, rather than via any conventional monetary policy transmission channel. We follow that study in terming this command-and-control channel for transmitting increased money growth to the real economy pseudo-monetary policy and show that it appears to be operating in many countries.

State-run commercial banks are important in many countries (La Porta et al. 2002), so pseudo-monetary policy might work elsewhere. Prior work shows state-run bank lending to be driven by political pressure, not profit maximization, in many economies (La Porta et al. 2002, 2003; Sapienza 2004; Berger et al. 2005; Dinc 2005; Carvalho 2014; Coleman and Feler 2015). Consistent with pseudo-monetary policy occurring elsewhere, prior work also shows state-run bank lending to be less procyclical than lending by private-sector commercial banks, and even countercyclical in some cases (Brei and Schclarek 2013; Bertay et al. 2015; Coleman and Feler 2015). This cross-country study links these two strands of work to present evidence suggesting 
pseudo-monetary policy might have economically important effects in many economies.

Briefly summarized, our baseline economy-level panel (2001 to 2010 spanning 40 economies) regressions link increased money growth to no subsequent change in bank lending or investment growth in economies whose commercial banking sector contain no large state-run banks, but to statistically and economically significantly larger increases in lending and investment in economies whose commercial banking sectors are more comprised of state-run banks. Our baseline bank-level panel (the largest commercial banks in the same 40 economies from 2001 to 2010) regressions show individual state-run banks significantly boosting lending after increased money growth, but otherwise similar private-sector banks in the same economies at the same time not doing so. These baseline findings are consistent with a pseudo-monetary policy transmission channel: monetary expansion letting state-run banks lend more by providing liquidity and political pressure making them do so.

Numerous robustness and identification tests support this interpretation and weigh against alternative causality scenarios. Simple macroeconomic reverse causality scenarios (e.g. credit demand shifts causing money growth and bank lending) are refuted unless somehow altered to explain why only state-run bank lending responds. Size, liquidity, and other balance sheet differences between state-run and private-sector banks do not explain these findings. Fixedeffects subsume all time-invariant bank-level (e.g. banks historical characteristics) and economylevel (e.g. legal origin) latent factors. Economy-year fixed effects subsume all time-varying economy-level latent factors (e.g. the general importance of state-owned enterprises in each economy each year) and their interactions with money growth (these interactions are also timevarying economy-level variables). The baseline results are present in periods of monetary expansion and contraction, in developed and developing economies, and survive a broad range of 
alternative specification robustness checks.

Three further sets of tests highlight pseudo-monetary policy as a parsimonious explanation of these patterns and weigh against alternative explanations. The first key set of tests clarifies the importance of political pressure in the mechanism inducing state-run banks to lend in concert with money growth. Faster money growth presages increased state-run bank lending significantly more strongly in years immediately prior to free elections, when political pressure on state-run banks to lend more is plausibly stronger than in other years (See e.g. Nordhaus 1975; Alesina et al. 1997; Dinc 2005; Micco et al. 2007). Private-sector bank lending shows no such pattern. Faster money growth presages state-run banks' lending growth more strongly in economies whose central banks are less independent - that is, more subject to political pressure (Crowe and Meade 2008). No such pattern is evident for lending by private-sector banks, suggesting that political pressure on state-run banks is necessary. Faster money growth ceases to presage individual state-run banks' lending immediately after their privatizations, consistent with privatization shielding their lending from political pressure (Megginson 2005). Thus, the baseline results are stronger in proportion to political pressure on state-run banks to lend as faster money growth makes this feasible (and on the central bank to boost money growth). ${ }^{1}$

Another set of tests highlights the crucial role of money growth in this mechanism. Prior work shows state-run bank lending to be less procyclical than private-sector bank lending (Brei and Schclarek 2013; Bertay et al. 2015; Coleman and Feler 2015). If state-run bank clients' demand for credit were less sensitive to the business cycle and central banks boosted money

\footnotetext{
1 State-run banks differ from private-sector banks in other ways. For example, state-run banks might have better information about central bank's plans, which might let them respond more forcefully to money growth changes than do private-sector banks. We focus on political pressure as the key difference because this is well-documented elsewhere (e.g., La Porta et al. 2002, 2003; Sapienza 2004; Berger et al. 2005; Dinc 2005; Carvalho 2014; Coleman and Feler 2015). We welcome future work exploring other differences.
} 
growth as recessions began, money growth could appear to presage state-run bank lending being higher than private-sector bank lending. If so, including these variables directly would erode the importance of money growth; but this is not observed. Above and beyond such effects, state-run bank lending always significantly correlates with past money growth.

Yet another set of tests confirms state-run banks to be a critical cog in the mechanism underlying the baseline results. More interventionist governments, which might press nonfinancial state-owned enterprises or politically connected firms to borrow and invest after money growth rises, might also have more state-run banks to supply such firms credit. However, faster money growth does not presage state-run bank lending more strongly where the reach of the state, measured in various ways, is larger. Indeed, faster money growth presages faster growth in both credit to the private sector and capital spending by the private sector in economies with more fully state-run commercial banking systems. Thus, the underlying mechanism appears to operate via state-run banks lending to the private sector.

The baseline results, interpreted through these sets of tests, are parsimoniously explained by pseudo-monetary policy. If state-run banks and central banks are more important and more subject to political pressure, politicians can better order up increased money growth and state-run bank lending to boost aggregate lending and capital spending. Our results suggest pseudomonetary policy can be an economically important contributor to the empirical relationship between money growth, bank lending, and investment where state banks comprise substantial fractions of national banking systems. Studies that fail to account for this may misconstrue the strength of traditional monetary policy transmission channels. While our results suggest that state-run banks can be a policy tool for reducing the substantial social costs of business cycles (Lucas 1987; Imrohoroglu 2008; Coleman and Feler 2015, Morck et al. 2011), other work links 
state-run banks to socially costly capital misallocation (e.g. La Porta et al. 2002, 2003; Sapienza 2004; Berger et al. 2005; Dinc 2005; Deng et al. 2011; Morck et al. 2011; Carvalho 2014). Public policy makers may thus wish to weight any short-run social benefits of pseudo-monetary policy against such long-run social costs.

\section{Data}

\subsection{Defining state-control}

Following La Porta et al. (2002), we identify each bank's ultimate owners, if any exist, each year as follows. First, a bank's large shareholders are defined as those with voting stakes of at least five percent. If a large shareholder is a natural person or state organ, the name is recorded. If a bank's large shareholder is a corporation, its large shareholders, its large shareholders' large shareholders, and so on are identified until we reach a natural person, state organ, or entity without a controlling shareholder. This exercise using voting stakes is necessary because banks can be controlled indirectly, through chains of holding companies or business group corporations, super-voting shares or other control enhancement devices. The voting stakes of all identified ultimate owners are aggregated at each level of the chain by assuming family members act in concert and state organs obey a single authority.

We define a bank's ultimate controlling owner as the ultimate owner whose combined voting stake is largest if that stake totals at least 10 percent. If the ultimate controlling owner is a state organ, the bank is classified as state-run. If the ultimate owner is not state-run or if there is no ultimate owner, the bank is classified as private-sector. In bank-level tests, our primary variable is a state-run indicator, $\delta_{i, t}$, set to one if bank $i$ is state-run in year $t$ and to zero otherwise. In economy-level tests, the bank governance importance variables weigh each bank in 
each category by lagged total net credit. Thus, $f_{j, t}$ measures the credit-weighted fraction of economy $j$ 's banking system that is state-run, as opposed to private-sector banks in year $t$ using credit weights from year $t-1$.

\subsection{Samples}

The bank-level sample begins with a 2001 cross-section of classifications of the ultimate controlling shareholders of commercial banks from Morck et al. (2011, Table 1). ${ }^{2}$ We determine the ultimate ownership of these banks for each year from 2001 through $2010 .{ }^{3}$ The result is a bank-level annual panel of ultimate controlling owner identities and stakes spanning 44 countries. The data for each bank begin in the year its ownership is first available. Ownership data are available for $79 \%$ of the sample in 2001 ; and for the rest after 2001 . To be in the sample, a bank must have comparable financial statements for two consecutive years, for reasons explained below.

Our basic sample merges the list of economies containing these banks with the IMF's International Financial Statistics (IFS), Government Financial Statistics (GFS), and World Economic Outlook (WEO) databases; the World Bank’s World Development Indicators (WDI) database; and Thomson-Reuters DataStream. This sample has economy-level data on monetary base growth, gross fixed capital spending and other variables. Because of missing GFS data on

${ }^{2}$ Morck et al. (2011) explain the construction of this initial cross-section in detail. They expand a cross-section of data from Caprio et al. (2007) for publicly listed banks to include every country's ten largest banks, listed or unlisted, ranked by 2001 assets in The Banker (2002), with ownership available in BankScope or other sources. We exclude export subsidy and business development banks, which are generally not deposit taking institutions subject to commercial banking regulation. Consequently, their lending behaviour may not be comparable to that of private-sector and state-run commercial banks.

3 This approach provides a stable panel, but omits new large banks and includes banks grown smaller over time. An alternative approach, using the largest few banks each year in each country, must contend with survival bias or banks entering the sample due, for example, to mergers. 
monetary base growth, our basic sample falls to 40 economies. Because fixed capital spending data are available only for 30 countries and interest rates for only 38 , smaller samples are used in tests involving these variables. Table 2 lists the countries in our basic sample, together with summary statistics for key variables.

\subsection{Money growth measure}

Broadly speaking, monetary policy can be a regulatory changes altering banks' ability to lend, market intervention altering key interest rates, or changes in money supply growth. We focus on money growth because regulatory changes are infrequent ${ }^{4}$ and because neither regulatory changes nor interest rates are easily comparable across economies. Moreover, the importance of any given regulatory change depends on multiple regulatory, legal, and other economy-specific considerations. In contrast, monetary aggregates change continuously and are readily comparable across countries. We further narrow our attention to monetary base growth because, among available monetary aggregates, this has the least direct overlap with the banking sector's balance sheet and the most consistent definition across countries. Nonetheless, we revisit changes in interest rates and bank capital regulations in robustness checks below.

Monthly base money growth is available for 40 countries in the IFS Database in the Central Bank Survey (IFS country tables, section 10, line 14). Base money is defined as currency in circulation (line 14a) plus central bank liabilities to other depository corporations (line 14c) plus central banks liabilities to other sectors (line 14d). For bank-level regressions, money growth in economy $j$ and year $t\left(\Delta M_{i, j, t}\right)$ is defined over twelve-month intervals immediately prior to the start of the bank $i$ 's fiscal year as $\Delta M_{i, j, t} \equiv\left(M_{i, j, t}-M_{i, j, t-1}\right) / M_{i, j, t-\mathrm{l}}$.

\footnotetext{
${ }^{4}$ The capital requirement stringency index of Barth, Caprio and Levine (2013) is unchanged from one year to the next for $81 \%$ of our bank-year observations.
} 
Thus, although base money growth is conceptually an economy-level variable, it can differ across banks in a given economy if their fiscal years differ. For example, a bank with a fiscal year beginning on January $1^{\text {st }}$ has a prior money growth rate calculated from the end of December to the end of December. In contrast, a bank whose fiscal year begins in March $1^{\text {st }}$ has its money growth rate calculated from the end of February in the previous calendar year through the end of February in the current calendar year. In economy-level tests, $\Delta M_{j, t}$ is calendar-year 12-month base money growth. These variables are winsorized at $10 \%$ to limit the influence of outliers.

We repeat our main tests using an alternative measure of monetary expansion: the drop in the country's key policy rate. The US Federal Reserve's monetary policy used such a policy rate, the federal funds rate, until 2012 when it switched to inflation targeting. Other central banks target inflation, money growth, or other variables, and so have no explicit policy rate. Consequently, the IMF IFS dataset provides a "monetary policy related interest rate" for only 22 economies for which we have bank ownership data. Interest rates tend to move together, so if no policy rate is available, we take the "discount rate", "lending rate" or "money market rate", in that order, as available in the IFS dataset. We define interest rate drop as minus one times the change in this rate over the prior 12 months. This gives us interest rate drops for 38 economies still short of the 40 for which money growth is available and the use of different interest rates in different economies potentially adds error in variables problems. Because of these issues, we use money growth as our primary measure and interest rate drop as a robustness test.

More radical monetary stimuli, such as regulatory changes may well coincide with especially rapid money growth, so our results could possibly reflect, in part at least, other dimensions of monetary policy also acting disproportionately through state-run banks. 
Additional robustness tests explore this below.

\subsection{Outcome Variables}

The outcome variables capture real growth in bank-level lending, economy-level lending, and economy-level fixed capital spending. These data are winsorized at $10 \%$ to limit outlier influence.

\subsubsection{Bank-level loan growth}

In bank-level regressions, the dependent variable is the bank's annual real growth in lending in local currency, but including lending in all currencies, from BankScope, defined as $\Delta$ credit $_{i, j, \mathrm{t}+1} \equiv\left(\operatorname{credit}_{i, j, t+1}-\operatorname{credit}_{i, j, t}\right) /$ credit $_{i, j, t}$, where the subscripts $i, j$, and $t$ index the bank, economy, and fiscal year, respectively. We define credit as gross lending where this is available because this measure is not mechanically affected by changes in discretionary loan loss provisions. ${ }^{5}$ However, if gross loans are unavailable, net loans are used. Real values are calculated by deflating nominal values using the economy's CPI index.

BankScope sometimes provides multiple accounting statements for a bank in one year. For example, BankScope provides separate financial statements for Jyske Bank A/S (Group) and Jyske Bank A/S in Denmark, but under the same bvd identifier number. To avoid artificially inflating the sample, only one financial statement is included each year for each $b v d$ identifier number. For better comparability across countries, the following procedure is applied. First, consolidated statements are preferred over unconsolidated statements if both are available. This

\footnotetext{
5 Bushman and Williams (2012) argue that U.S GAAP and IFRS allow discretion in loan provisioning and discretionary loan provisioning practices, and that this varies across countries.
} 
is because overall lending by a bank group is arguably more important to the economy as a whole than is lending by one of its member firms. Indeed, financial conglomerates, especially conglomerates with banks across countries, might respond to a monetary policy shift with internal capital market transactions that cancel out across the group as a whole (Campello, 2002). However, unconsolidated statements are used in robustness tests. Second, "audited" or "qualified" statements are preferred over "not audited" or "unqualified" statements if both are available. Finally, statements based on international accounting standards (codes IFRS, IFRSNFC or IAS) are preferred over statements using local accounting systems (designated "local GAAP" or "regulatory") if both are available.

Despite these filters, a few extreme real growth rates in loans remain. We identify some as resulting from bank mergers and acquisitions. In these cases, BankScope either discontinues data for one of the merged banks and continues data for the merged entity under the other's identification code or discontinues data for both and starts recording data for a new bank. The former procedure can generate extreme loan growth rates. Spot checking the data reveals M\&As responsible for most extreme observations. We therefore drop 39 bank-year observations with real annual gross loan growth outside plus or minus $50 \%$ in the main sample, but restore them for robustness tests.

We have controlling shareholder data for the largest banks in each economy, and use these in our bank-level loan growth tests. While these banks are few in number in each country, they constitute a large fraction of each economy's banking sector (see Morck et al. (2011) for details). We therefore anticipate that our bank-level results can provide useful insights into economy-level questions. 


\subsubsection{Economy-level Aggregate Loan Growth}

Economy-level gross lending is the change in "domestic credit provided by banking sector" from the World Development Indicators (WDI) database, which provides domestic credit extended by the banking sector divided by GDP. We obtain our variable by multiplying this ratio by GDP in current local currency, deflate these nominal aggregates by the CPI index, and calculating. aggregate real annual growth in lending, $\Delta$ credit $_{j, t+1}$, for each economy-year observation $j, t$ as $\Delta$ credit $_{j, \mathrm{t}+1} \equiv\left(\right.$ credit $_{j, t+1}-$ credit $\left._{j, t}\right) /$ credit $_{i, t}$, . This is a broad measure of banking sector credit growth, which also includes lending by other banks and non-bank financial institutions,

\subsubsection{Economy-level Fixed Capital Spending Growth}

We look for the possible real effect of money growth in gross fixed capital spending growth. This is because aggregate investment is by far the most volatile and pro-cyclical component of gross domestic product (GDP), and plays a key role in the accelerator effect (Samuelson, 1939), whereby firms boost investment when they expect higher future sales. Thus, to explore the transmission of money growth via bank lending to economic growth, we focus on aggregate investment.

We take gross fixed capital spending from the IMF's International Financial Statistics database: National Accounts and Population line 93e. Gross fixed capital spending is the total value of fixed asset acquisitions, less disposals plus certain additions to the value of nonproduced assets (such as subsoil assets or major improvements in the quantity, quality, or productivity of land). We use each economy's PPI index to deflate these data. The economy's real annual growth in capital spending is $\Delta$ capex $_{j, t+1} \equiv\left(\operatorname{capex}_{j, t+1}-\operatorname{capex}_{j, t}\right) /$ capex $_{j, t}$, again measured over the year following that over which money growth is measured. Capital 
spending data are quarterly; however, we measure capital spending growth over a full year because capital investment is unlikely to be an instantaneous response.

\subsection{Control Variables}

All economy-level regressions control for economy fixed-effects. The bank-level regressions include bank fixed-effects, and most also include either year or economy-year fixed-effects. As we explain below, our bank-level baseline regressions follow Kashyap and Stein (2000) in including money growth interactions with controls based on bank size, the log of a bank's prior fiscal year-end total assets in US dollars, and bank liquidity, defined as a bank's sum of government securities, cash, and accounts due from other banks over total assets. Table 1 provides details as to their sources and construction.

\subsection{Summary Statistics}

Table 2 provides means and standard deviations of money growth, growth in lending, and growth in capital spending. On average all countries experience monetary expansion and positive real gross loan growth. There is greater heterogeneity in real fixed capital growth: among the countries for which we have data, twenty two register a positive average and eight a negative average. The table also shows which countries have more fully state-run versus private-sector commercial banking systems.

Table 3 Panel A displays pairwise cross-country correlation coefficients of loan growth, money growth, fractions of banks state-run, and key controls in the economy-level sample. Panel B displays correlations of loan growth, money growth, banks state-run, bank size and liquidity in the bank-level sample. In the bank sample, loan growth correlates significantly positively with 
money growth and lagged liquidity. State-run banks are more liquid and smaller than privatesector banks. Bank liquidity and bank size are negatively correlated.

\section{Empirical Methodology and Results}

\subsection{Baseline economy-level regressions}

Our economy-level regressions use differences in country $j$ 's year $t$ base money growth, $\Delta M_{j, t}$, to explain differences in either its aggregate real credit growth, $\Delta c r e d i t_{j, t+1}$, or its aggregate real capital investment growth, $\Delta$ capex $_{j, t+1}$, in year $t+1$. These regressions take the form

[1a] $\quad \Delta$ credit $_{j, t+1}=a+b \Delta M_{j, t}+$ controls $+e_{j, t}$,

[1b] $\quad$ scapex $_{j, t+1}=a+b \Delta M_{j, t}+$ controls $+e_{j, t}$,

To explore differences in this relationship associated with $f_{j, t}$, the state-run fraction of country $j$ 's banking system in year $t$, let the coefficient $b$ in [1] vary with $f_{j, t}$. A varying parameter specification thus replaces $b$ in [1a] and [1b] with the linear function

$$
b\left(f_{j, t}\right) \equiv b_{0}+b_{1} f_{j, t}
$$

Substituting [2] into [1], controlling for the main-effect of the state-run banking measure, $f_{j, t}$, and economy fixed-effects, denoted $\lambda_{j}$, yields our baseline economy-level regression specifications

$$
\begin{aligned}
& \Delta \text { credit }_{j, t+1}=a_{1} f_{j, t}+\left(b_{0}+b_{1} f_{j, t}\right) \Delta M_{j, t}+\sum_{i} d_{j} \lambda_{j}+e_{j, t}, \\
& \text { scapex }_{j, t+1}=a_{1} f_{j, t}+\left(b_{0}+b_{1} f_{j, t}\right) \Delta M_{j, t}+\sum_{i} d_{j} \lambda_{j}+e_{j, t}
\end{aligned}
$$

in which the economy fixed-effects subsume $a$, the intercept in [1].

These regressions test for whether differences in money growth presage differences in aggregate credit or investment growth differently where the banking system is more state-run. 
All country-level regressions cluster residuals $e_{j, t}$ by economy, with Eurozone countries one cluster for this purpose only. If increases in money growth presage greater increases in credit and capital growth in countries with higher fractions of state-run banks, the estimated coefficients $b_{1}$ would be significantly positive.

Regressions 4.1 and 4.2 in Table 4 summarize these results. Regression 4.1, based on [3a], associates one percentage point higher base money growth rate over the prior year with a statistically and economically significant 0.23 percentage points higher aggregate credit growth in an economy whose banking system is entirely state-run than in an economy whose banking system is fully private-sector. Regression 4.2 , based on [3b], links the same increase in money growth to a statistically and economically significant 0.79 percentage point higher aggregate capital spending growth where the banking system is entirely state-run versus where it is entirely private-sector.

In both regressions, the money growth main-effects attract negative coefficients. That in 4.A2 is significant, implying that a rise in money growth anticipates reduced aggregate capital spending growth in economies whose banking systems are less than $0.27 / 0.79=34 \%$ state-run. If central banks tend to boost money growth as slowdowns in capital spending impend, and Bouis et al. (2013) and others correctly conclude that a monetary stimulation is generally ineffective through conventional private-sector channels, this result could follow.

If monetary expansion is ineffective in boosting lending by large private-sector banks, but effective in boosting lending by similar state-controlled banks, macro-level monetary neutrality might depend on the ownership structure of the country's banks. Money growth might be neutral in economies whose banking systems consist mainly of large private-sector banks, but effective in boosting lending and investment in proportion to the importance of state-run banks. 
Our findings thus suggest a possible route for reconciling mixed findings about the effectiveness of monetary policy after the recent financial crises (e.g., Deng et al., 2011; Bouis et al., 2013; Chakraborty, Goldstein and MacKinlay, 2015).

Obviously, these economy-level regressions demonstrate only correlations. Inferring that a more fully state-run banking system more effectively transmits money growth into real credit and capital spending growth requires additional tests, which the remainder of this section and the next section develop.

\subsection{Fixed effects and bank-level heterogeneity restrict feasible explanations}

Our first set of additional tests utilizes identification by disaggregation, as introduced by Kashyap and Stein (2000). After exhaustively surveying estimation techniques for assessing the efficacy of monetary stimulus policies, they conclude that "to make further progress on this difficult identification problem, one has to examine lending behaviour at the individual banklevel" because different economy-level causality scenarios require that "the effect of monetary policy on lending should be more pronounced for some banks than for others." The issue at hand is amenable to this approach because, if state-run banks transmitted monetary growth more reliably than do private-sector banks, this would stand out in bank-level lending data.

Our bank-level tests, which parallel the economy-level relationship [1], have the form [4] $\Delta$ credit $_{i, \mathrm{j}, t+1}=a+b \Delta M_{i, j, t}+$ controls $+e_{i, j, t}$,

with $i, j$ and $t$ indexing banks, countries, and bank fiscal years, respectively. All bank-level regressions cluster by economy, with the Eurozone one cluster after the euro introduction

The proportionality relationship [2] is a dichotomy at the bank-level. Individual banks are either state-run and the state-run bank indicator variable, $\delta_{i, j, t}$, is one, or private-sector, and 
$\delta_{i, j, t}=0$. This indicator is allowed to shift the coefficient $b$ in [4]. That is, the fixed parameter $b$ is replaced by

$$
b\left(\delta_{i, j, t}\right) \equiv b_{0}+b_{1} \delta_{i, j, t}
$$

Substituting [5] into [4], and controlling for the main-effect of the state-run bank indicator and bank fixed-effects, $\lambda_{i}$, yields the bank-level specification

[6a] $\Delta$ credit $_{i, \mathrm{j}, t+1}=a_{1} \delta_{i, j, t}+\left(b_{0}+b_{1} \delta_{i, j, t}\right) \Delta M_{i, j, \mathrm{t}}+\sum_{i} d_{i} \lambda_{i}+e_{i, j, t}$.

This is essentially a test for differences between state-run and private-sector banks in how changes in lending track changes in money growth. Fixed effects subsume the intercept $a$ in [4].

Including year fixed-effects, denoted $\lambda_{t}$ in [6b] or economy-year fixed-effects, denoted $\lambda_{j, t}$ in $[6 \mathrm{c}]$ yields the bank-level difference-in-difference specifications

[6b] $\Delta$ credit $_{i, \mathrm{j}, t+1}=a_{1} \delta_{i, j, t}+\left(b_{0}+b_{1} \delta_{i, j, t}\right) \Delta M_{\mathrm{i}, \mathrm{j}, \mathrm{t}}+\sum_{i} d_{i} \lambda_{i}+\sum_{t} d_{t} \lambda_{t}+e_{i, j, t}$

[6c] $\Delta$ credit $_{i, j, t+1}=a_{1} \delta_{i, j, t}+\left(b_{0}+b_{1} \delta_{i, j, t}\right) \Delta M_{i, j, t}+\sum_{i} d_{i} \lambda_{i}+\sum_{j, t} d_{j, t} \lambda_{j, t}+e_{i, j, t}$,

In $[6 b]$ and $[6 c]$, bank fixed-effects subsume the intercept $a .^{6}$

Regressions 4.3 through 4.5 summarize these tests. Regression 4.3, based on [6a], controls for bank fixed-effects, links a one percentage point increase in money growth to a 0.30 percentage point statistically significantly larger increase in lending growth by a state-run bank than by a private-sector bank. This exposes an economically significant heterogeneity in the bank-level data: lending growth by individual state-run banks rises following an increase money growth; lending by individual private-sector banks in the same economy does not. Regressions 4.4 and 4.5 refine specifications [6b] and [6c] by including successively more nuanced fixed

6 In [6a], [6b] and [6c], if the state-run bank indicator is constant through time for all banks, the state-run bank dummy is perfectly collinear with the bank fixed-effects. Because five banks switch status, we can theoretically estimate $a_{1}$ and $b_{0}$; however we refrain from attaching economic significance to them. 
effects, yet generate qualitatively similar results: after money growth changes, state-run banks change their lending more than private sector banks do. The main-effect money growth coefficients in the bank-level regressions are insignificant, suggesting money growth presages no growth in private-sector bank lending. ${ }^{7}$

Successively more nuanced fixed effects in 4.1 through 4.5 successively restrict alternative explanations. Economy fixed-effects in 4.1 and 4.2 subsume omitted time-invariant economy characteristics; as do bank fixed-effects in 4.3 through 4.5 because economy dummies are linear combinations of bank dummies (no bank switches economy and multinational banks are assigned distinct fixed-effects in each economy). This precludes alternative explanations turning on time-invariant economy-level differences, such as legal origin, cultural variables. Bank fixed-effects in in 4.3 through 4.5 further preclude time-invariant bank factors, such as initial balance sheet characteristics. Year fixed-effects in 4.4 further subsumes global timevarying latent factors, such as the state of the global economy.

Regression 4.5 provides the strongest restrictions by including bank and economy-year fixed-effects. The latter subsume all time-varying economy-level latent variables, such as unemployment rates, inflation rates, or other such time-varying country-level variables as well as their interactions with money growth (because such interactions are also time-varying economylevel variables). Thus, 4.5 precludes money growth affecting credit demand differently under different economic conditions, governments with different attention to free markets, different trade conditions, and so on being relevant to explaining our baseline regressions.

\footnotetext{
${ }^{7}$ When economy-year fixed-effects are included main effect of money growth is dropped because only $4 \%$ of banks have fiscal year ends different from those of other banks in the same economy. Including or excluding these banks does not alter the baseline results. The main effect of the state run bank indicator is driven by five banks that are privatized in our sample period. Excluding these banks do not alter our results. We examine bank privatizations in more detail below.
} 
Finally, bank-level variation lets 4.3 through 4.5 refute broad classes of macro-level reverse causality scenarios in which another macroeconomic variable causes a general increase in money growth and credit demand. Such precluded scenarios include technology shocks, market expansions, regulatory reforms, or other such changes leading monetary authorities to boost money growth to accommodate anticipated increases in credit demand and investment. This is because the bank-level results limit feasible alternative causality scenarios to those that explain why only state-run banks' lending responds to changes in the macroeconomic variable.

\subsection{Baseline bank-level regressions}

One mechanism permitting bank-level heterogeneity is that in Kashyap and Stein (2000). They envision lending-constrained small illiquid banks responding to money growth, which relaxes those constraints, but large liquid banks, already lending optimally, not responding. Finding evidence of precisely this heterogeneity in bank-level regressions, they argue that their banklevel findings identify a bank credit monetary policy transmission channel at the economy-level. If state-run banks were smaller or less liquid than private-sector banks, our state-run indicator might merely proxy for such lending constraints. In fact, the simple correlations in Table 3 show state-run banks smaller but more liquid than private-sector banks.

To explore this, we modify the bank-level regressions to let bank size and bank liquidity, denoted $x_{k, i, j, t}$ for $k \in\{$ size, liquidity $\}$ join the state-run bank indicator in modulating how between differences in money growth presage differences in bank-credit growth. This is operationalized by replacing $b$ in [4] with

$$
b\left(\delta_{i, j,},\left\{x_{k, i, j, t}\right\}\right) \equiv b_{0}+b_{1} \delta_{i, j, t}+\sum_{k} \gamma_{k} x_{k, i, j, t}
$$

rather than with the expression in [5]. 
This yields another set of bank-level difference-in-difference regressions, which we refer to below as our baseline bank-level regressions,

$$
\begin{aligned}
\operatorname{sredit}_{i, j, t+1}= & a_{1} \delta_{i, j, t}+\left(b_{0}+b_{1} \delta_{i, j, t}+\sum_{k} \gamma_{k} x_{k, i, j, t}\right) \Delta M_{i, j, t}+\sum_{k} c_{k} x_{k, i, j, t}+ \\
& \sum_{i} d_{i} \lambda_{i}+\sum_{t} d_{t} \lambda_{t}+e_{i, j, t} .
\end{aligned}
$$

$$
\begin{aligned}
\operatorname{credit}_{i, j, t+1}= & a_{1} \delta_{i, j, t}+\left(b_{0}+b_{1} \delta_{i, j, t}+\sum_{k} \gamma_{k} x_{k, i, j, t}\right) \Delta M_{i, j, t}+\sum_{k} c_{k} x_{k, i, j, t}+ \\
& \sum_{i} d_{i} \lambda_{i}+\sum_{j, t} d_{j, t} \lambda_{j, t}+e_{i, j, t} .
\end{aligned}
$$

These explore how a unit change in money growth presages different changes in lending growth by state-run versus private-sector banks of comparable size, liquidity and initial or time-invariant characteristics in each country each year. Bank fixed-effects, $\lambda_{i}$ in [8a] and [8b], control for all bank- and country-level time-invariant latent factors; economy-year interaction fixed-effects, $\lambda_{j, t}$, in [8b], control for all time-varying latent variables and their interactions with money growth. Again, clustering is by economy, the Eurozone being one cluster after the euro introduction.

The baseline bank-level regressions are 4.6 and 4.7. If state-run bank size or liquidity drove these results, the interactions of bank size and liquidity with money growth would be significant and leave the interaction of the state-run bank indicator with money growth insignificant. This is not observed. The interactions with size and liquidity are insignificant, and that with the state-run indicator remains significant - indeed its point estimate barely budges. ${ }^{8}$

These findings do not necessarily contradict Kashyap and Stein (2000). Their analysis exploits the unusual structure of the U.S. banking system: the thousands of very small independent banks that persist as a legacy of its Depression era regulations restricting banks to a

\footnotetext{
8 Kashap and Stein (2000) measure bank size using a large bank indicator (set to one for banks among the largest percent in their economies, zero otherwise) and measure liquidity as cash plus all securities and funds due from other banks, all over total assets. Results qualitatively similar to those in regressions 4.6 and 4.7 ensue after substituting either or both of these alternative measures.
} 
single branch (Calomiris and Haber, 2014). Our analysis uses only the largest, and presumably most liquid, banks in each economy. The comparatively limited variation in bank size and liquidity in our sample understandably makes the Kashyap and Stein (2000) effect difficult to find. For our purposes, this helps because it also makes that effect less likely to interfere with our primary task. ${ }^{9}$

We therefore conclude that the Table 4 findings are unlikely to be an artefact of state-run and private-sector banks being of systematically different size or liquidity. Rather, state-run bank's lending is significantly more related to prior money growth than is lending by a privatesector bank of similar size and liquidity in the same country at the same time under similar conditions. Indeed, state-run bank lending alone changes after money growth changes; privatesector bank lending does not. This suggests a mechanism distinct from that modelled by Kashyap and Stein (2000), such as state-run banks obeying politicians' orders to lend more after money growth loosens their lending constraints.

\section{Robustness}

We consider the economy level regressions 4.1 and 4.2 and the bank-level regressions 4.6 and 4.7 in Table 4 our baseline results. These survive a battery of robustness checks. In describing these, we say the results are qualitatively similar if we see an identical pattern of signs and significance and comparable point estimates. Where results are not qualitatively similar, we provide details. The reader can omit this section without loss of continuity.

\subsection{Alternative definitions of key variables}

\footnotetext{
9 For further work on the Kashyap and Stein (2000) hypothesis, see e.g. Ivashina and Scharfstein (2010).
} 
Our first robustness check measures monetary expansion by interest rate drops, rather than base money growth, over the prior 12 months. Table 5 shows qualitatively similar results to those in Table 4: interest rate drops presage larger increases in lending and investment where banking systems are more fully state-run; individual state-run banks boost lending after policy rate drops while otherwise similar individual private sector banks in the same economies at the same time do not. The sole difference is that the main effect coefficient on interest rate drop in the economy-level regression explaining investment growth is insignificant - though the point estimate remains negative.

As a second robustness check, we construct an alternative aggregate bank credit growth measure by summing the gross credit extended by all banks in BankScope dataset in each economy each year, and constructing a real growth rate in this aggregate. This measure can be criticized for relying on the incomplete or time varying coverage of banks in BankScope and for omitting non-bank financial institutions of many sorts. Repeating our tests with this alternative measure of economy-level bank credit growth also generates qualitatively similar results.

We also check the robustness of our classification of commercial banks as private-sector or state-run. Section 2.1 infers state control if a bank's largest ultimate controlling shareholder is one or more state entities and their combined control block is at least $10 \%$. Banks tend to be controlled with stakes substantially higher than this if the state owns any nontrivial stake. Rerunning the classification algorithm using a 5\% threshold generates precisely the same classification as using the $10 \%$ threshold. Using a $20 \%$ threshold moves only one state-run bank to the private sector list. Rerunning the baseline regressions generates results virtually identical to those in the table.

Our bank-level data include only commercial banks, which take deposits and lend out 
money because these are the institutions through which monetary policy is thought to operate. The data exclude state-run development banks such as Brazil's BNDES, which lend directly from government coffers to selected businesses because their responses to money growth may not be comparable to that of commercial banks. Nonetheless, we expand the samples to include these institutions as a robustness check. We start with banks that BankScope flags as "specialized governmental credit institution" larger than the smallest commercial bank in the same country in the beginning of our sample period. The size filter maintains comparability with our original sample. Export banks, central banks and reserve banks are excluded. The remaining banks are merged into our bank-level data and our economy-level variables are recalculated using the expanded sample. In most countries, the fraction of the banking system that is state-run changes little. The major exception is Brazil, where the mean fraction state-run rises from $43 \%$ to $65 \%$. Our baseline results all continue to hold.

Some studies (Caprio et al. 2007; Laeven and Levine 2009; Morck et al. 2011) partition private-sector banks into those that are widely held and those that have a controlling shareholder. To explore this, we define controlling shareholder banks as private-sector banks with a natural person or family as an ultimate controlling shareholder and widely held private-sector banks as those with no ultimate controlling shareholder. Rerunning the regressions partitioning banks into state-run, widely held, and controlling shareholder banks generates results qualitatively similar to the tables. Higher money growth presages faster growth in state-run bank lending, but not in lending by either type of private-sector bank. Higher money growth presages increased growth in aggregate lending and investment in economies where state-run banks are more predominant, but not where either class of private-sector bank is more predominant.

Our data contain no foreign subsidiaries of other countries' state-run banks, but some 
private-sector banks in some economies are subsidiaries of foreign banks. These may have better access to international money markets than do purely domestic banks, and thus might potentially be less affected by a domestic money growth. Also, the importance of foreign banks might correlate with overall openness. Using our data on controlling owners for each bank each year, we set a new dummy variable to one if the bank is foreign-controlled that year and to zero otherwise. We then recalculate a new set of credit-weighted economy-level bank governance variables denoting the importance of state-run banks, domestic private-sector banks, and foreigncontrolled banks. We rerun the baseline bank-level regressions, first dropping all foreigncontrolled banks, and then controlling for the foreign-controlled bank dummy's interaction with money growth. We rerun the baseline economy-level regressions analogously - first using the revised importance of state-run banks measure and then controlling for the main-effect and interaction with money growth of the foreign-controlled bank importance measure. These exercises generate results qualitatively similar to the baseline regressions, and the coefficients on the foreign-bank main-effects and interactions are uniformly insignificant.

Another possibility is that domestic banks may be global banks that have subsidiaries abroad and as a result their loan growth may be less affected by domestic money growth. This is especially a concern given that we use consolidated financial statements; however, as mentioned above using unconsolidated statements yield similar results. Regardless, we identified banks that control other banks in other countries and labelled them as global banks. Dropping these banks yields similar results in baseline regressions. Keeping these banks but recalculating our main variables denoting the importance of state-run banks, domestic private-sector banks, and global banks also yields qualitatively similar results to the baseline regressions. 


\subsection{Outliers and specification tests}

Money growth and bank-level loan growth are winsorized at $10 \%$, and observations with absolute value of loan growth above 50\% are dropped. Winsorizing at 5\%, not winsorizing, and retaining the extreme values all yield qualitatively similar results. Cook's D statistics show no economy consistently over the $4 / \mathrm{n}$ threshold in any regressions. In the economy-level lending growth regressions, only Venezuela has several high values, and dropping that economy does not alter the baseline results. In the capital spending growth regressions, only the United Kingdom has three high values and dropping that economy improves the regression fit slightly without altering the signs, significance patterns and approximate point estimates. In the bank-level regressions, no country stands out for having a high incidence of high Cook's D statistics.

Economy-level and bank-level panel regressions cluster by economy, with Euro-zone countries as one cluster. Petersen (2009) recommends this as a conservative approach using panel data of this sort, two-way clustering, by economy and by year, yields qualitatively similar results. Not clustering or clustering only by year yields uniformly better p-levels. Dropping all fixed-effects yields qualitatively similar results with lower p-levels, as does rerunning the banklevel regressions with economy fixed-effects instead of bank fixed-effects.

We use consolidated data for banks that report both consolidated and unconsolidated figures. Using unconsolidated data yields qualitatively similar results.

Bank-level characteristics other than size and liquidity might also interact with money growth in bank lending decisions. We therefore consider two other key bank balance sheet variables: total deposits and total equity, both scaled by total assets and lagged one year. Rerunning our baseline bank-level regressions including these variables and their interactions with money growth (not shown) does not affect our main results. The coefficients of the 
interaction of these additional variables with money growth are uniformly insignificant and the interaction of money growth with the state-run bank indicator always attracts a positive significant coefficient.

Finally, we check the acceptability of the linearity assumptions in our baseline regressions. Replacing the dependent variables and money growth with their logarithms in all the baseline regressions generates similar patterns of signs and significance levels and does not significantly improve the regression fits. ${ }^{10}$ Nonlinearity arises as a possible explanation of the negative main effect on money growth in the baseline regression 4.2 , so we conduct additional nonlinearity robustness checks there. The point estimates in that regression combine in [2] to imply that a unit increase in money growth boosts aggregate real capital spending growth by $b\left(f_{j, t}\right)=-0.27+0.79 f_{j, t}$, where $f_{j, t}$ is the fraction of the banking system state-run. This implies that a unit boost to money growth actually decreases real capital spending growth if state-run banks constitute less than $0.27 / 0.79(=34 \%)$ of the banking system. However, [2] imposes the linear specification $b\left(f_{j, t}\right) \equiv b_{0}+b_{1} f_{j, t}$ on how this coefficient can vary with the importance of state-run banks. This might drive the intercept $b_{0}$ into negative territory artificially if the positive slope estimate $b_{1}$ is primarily driven by observations where $f_{j, t}$ is relatively high. If so, a nonlinear variant of [2] is required. Rerunning [2] adding a quadratic term $b_{2} f_{j, t}^{2}$ leaves only the linear terms significant and does not improve the fit. Rerunning [2] with the piecewise linear specification - that is, letting $b\left(f_{j, t}\right) \equiv b_{0}+b_{1} f_{j, t}^{L}+b_{2} f_{j, t}^{H}$ - allows different coefficient on money growth where the state-run fraction of the banking system state-run is higher versus

\footnotetext{
${ }^{10}$ Because these variables can be negative, their logarithmic transforms are calculated by adding one and taking natural logarithms.
} 
lower than a breakpoint. ${ }^{11}$ Regardless of the breakpoint used, the intercept remains significantly negative, its point estimate changes little, and the piecewise linear specifications do not detectably improve the regression's fit. Nonlinearity is only evident if the breakpoint is very low, and far lower than $34 \%$. Where state-run banks constitute $5 \%$ or less of the banking system, the importance of state-run banks no longer significantly alters the correlation between prior money growth and capital spending growth. We conclude that the linearity in [2] does not artificially generate the negative main effect on money growth in $4.2 .^{12}$

\section{$5 \quad$ Consideration of alternative mechanisms}

This section considers alternative explanations of our baseline economy level and bank-level regressions. By showing that faster money growth presages faster lending growth by state-run banks than by private-sector banks of comparable size and liquidity in the same economies in the same years, the bank-level regressions narrow the field to alternative explanations with scope for this bank-level heterogeneity. Two classes of alternative explanations are considered: (1) explanations turning on variables other than money growth differentially affecting state-run and private sector lending and (2) explanations turning on other measures of state power making state-run bank lending differ from private sector bank lending. The reader can skip this section without loss of continuity.

\subsection{Money growth appears crucial}

We posit that a boost in money growth precedes a boost in state-run bank lending because faster money growth lets banks lend more and political pressure makes state-run banks lend more. This

\footnotetext{
${ }^{11}$ This defines $f_{j, t}^{L} \equiv f_{j, t}$ if $f_{j, t}<f^{*}$ and $f_{j, t}^{L} \equiv f^{*}$ if $f_{j, t} \geq f^{*}$ and define $f_{j, t}^{H} \equiv 0$ if $f_{j, t}<f^{*}$ and $f_{j, t}^{H} \equiv f_{j, t}-f^{*}$ if $f_{j, t} \geq f^{*}$, repeating this exercise for breakpoints $f^{*}=1 \%, 5 \%, 10 \%, 15 \%, \ldots$ to $50 \%$.

${ }^{12}$ Repeating all these tests for 4.1 reveals no nonlinearity issues.
} 
sub-section considers the possibility that differences in state-run banks' lending might be tracking changes in some other time-varying economic policy or economy characteristic, $p_{j, t}$, rather than changes in money growth. For such a variables rather than money growth, to explain our baseline bank-level findings, it must be correlated with money growth and must lead to different behaviour changes in state-run versus private-sector banks. One way this might arise is if state-run banks' borrowers respond differently to some variable that correlates with money growth. This is testable by letting such variables interact directly with the state-run bank variables. If they were proxying for money growth, the magnitude and significance of the interactions of money growth with the state-run bank variables would fade.

To test for this, we consider economy-level regressions of the form

[9a] $\quad \Delta$ credit $_{j, t+1}=a_{1} f_{j, t}+\left(\beta_{0}+\beta_{1} f_{j, t}\right) p_{j, t}+\left(b_{0}+b_{1} f_{j, t}\right) \Delta M_{j, t}+\sum_{i} d_{j} \lambda_{j}+e_{j, t}$,

[9b] $\Delta$ capex $_{j, t+1}=a_{1} f_{j, t}+\left(\beta_{0}+\beta_{1} f_{j, t}\right) p_{j, t}+\left(b_{0}+b_{1} f_{j, t}\right) \Delta M_{j, t}+\sum_{i} d_{j} \lambda_{j}+e_{j, t}$,

and bank-level regressions of the form

[10a] $\Delta$ credit $_{i, j, t+1}=a_{1} \delta_{i, j, t}+\left(\beta_{0}+\beta_{1} \delta_{i, j, t}\right) p_{j, t}+\left(b_{0}+b_{1} \delta_{i, j, t}+\sum_{k} \gamma_{k} x_{k, i, j, t}\right) \Delta M_{i, j, t}+$

$$
\sum_{k} c_{k} x_{k, i, j, t}+\sum_{i} d_{i} \lambda_{i}+\sum_{t} d_{t} \lambda_{t}+e_{i, j, t}
$$

$$
\begin{aligned}
\operatorname{sredit}_{i, j, t+1}= & a_{1} \delta_{i, t}+\left(\beta_{0}+\beta_{1} \delta_{i, j, t}\right) p_{j, t}+\left(b_{1} \delta_{i, j, t}+\sum_{k} \gamma_{k} x_{k, i, j, t}\right) \Delta M_{i, j, t}+ \\
& \sum_{k} c_{k} x_{k, i, t}+\sum_{i} d_{i} \lambda_{i}+\sum_{j, t} d_{j, t} \lambda_{j, t}+e_{i, j, t}
\end{aligned}
$$

These regressions essentially run horse-races to see which best explains the left-hand side variables: interactions of state-run banking with money growth or interactions of state-run banking with the suspected omitted variable, $p_{j, t}$. If including the additional terms in [9] and [10] leaves $b_{1}$ insignificant - or even just substantially reduced in magnitude - the alternative explanation merits attention. However, if including the additional terms leaves $b_{1}$ significantly positive and little changed in magnitude, our baseline results merit further investigation. The 
following tests run such horse-races against plausible candidates for heterogeneity associated with such missing variables.

One possibility is heterogeneous borrower responses to a fiscal stimulus. If state-run banks' borrowers were more sensitive than private-sector banks' borrowers to a fiscal stimulus, demand for credit from state-run banks could rise faster after a fiscal stimulus than does demand for credit from private-sector banks. If the central bank accommodated this by letting money growth rise, letting actual lending subsequently rise, our baseline results could ensue, but increased borrowing from state-run banks and increased investment by their borrowers would be causing money growth, rather than the converse.

Such scenarios are not a priori excludable. For example, a fiscal stimulus might entail spending on infrastructure. If infrastructure construction firms were disproportionately state-run bank clients, their capital expenditure plans could disproportionately boost demand for credit at state-run banks. Likewise, a fiscal stimulus effected by partially subsidizing investment by nonfinancial state-owned enterprises or politically-connected private-sector firms, which borrowed the remaining capital costs from state-run banks, could disproportionately boost demand for credit at state-run banks.

Table 6 regressions 6.1 to 6.4 explores this alternative explanation using specifications [9] and [10] to let the prior year's fiscal stimulus operate differently via state-run banks. In all four regressions, $b_{1}$ is positive and significant, its magnitude little changed from its Table 4 analogues and the additional main effects and interactions are uniformly insignificant. Faster money growth presages more increased lending and capital spending where state-run banks are more important and presages increased lending by state-run banks, but not by otherwise similar private-sector banks in the same country at the same time; a fiscal stimulus presages one of 
these.

A second possibility is heterogeneous borrower responses to currency depreciation. Exchange rate drops can accompany changes in money growth (Fleming 1962; Mundell 1963). An exchange rate drop can spur both exports and inward foreign direct investment, and might thus spur lending associated with either or both. This scenario also has scope for bank-level heterogeneity. First, though our sample excludes export banks, some countries charge generic state-run banks with export promotion - that is, with lending to exporters or exporters' foreign customers. A lower exchange rate could spur demand for export-related loans, and if state-run banks disproportionately provided these, their lending might rise disproportionately as the exchange rate falls. Second, currency depreciation can attract inward foreign direct investment (Froot and Stein, 1991). If state-run banks' clients disproportionately formed joint ventures or partnerships with foreign entrants, we might observe state-run banks' lending rising disproportionately as the currency drops. In either case, if money growth rises as the currency drops, our baseline results might ensue.

Regressions 6.5 to 6.8 therefore repeat the exercise above, but using $p_{j, t}$, the prior year's exchange rate depreciation (percent change in local currency units per U.S. dollar, positive values implying local currency depreciation). The objective of these regressions is to let exchange rate depreciation compete with money growth to explain the differences associated with state control over banks in the baseline regressions.

In both economy-level regressions, $\beta_{1}$ is significantly positive; in both bank-level regressions, it is insignificantly negative and the exchange rate depreciation main-effect is significantly negative. The economy-level regressions are thus consistent with faster lending growth after an exchange rate drop if more banks are state-run; but the bank-level regressions 
implicate something other than differential lending behaviour by the two types of banks.

More important to the issues at hand, $b_{1}$ remains positive and significant across all four regressions, its magnitudes little changed from Table 4. The bank-level results are consistent with faster money growth, but not steeper exchange rate drops, presaging faster lending growth by individual state-run banks than by otherwise similar individual private-sector banks in the same country at the same time. The economy-level results show that controlling for economylevel effects associated with currency depreciation does not disturb the baseline economy-level results regarding state-control over banks and money growth.

A third possibility is heterogeneous borrower or state-run bank responses over the business cycle. State-run banks' borrowers might be less sensitive than private-sector banks' borrowers to the business cycle. For example, if state-run banks' clients were disproportionately regulated utilities or other recession-proof industries, credit demand at state-run banks might be substantially less procyclical than at private-sector banks. If activist monetary authorities ran countercyclical monetary policies, increased money growth might spuriously presage state-run banks' lending rising above private-sector banks' lending.

To explore this, we take $p_{j, t}$ as the prior year's output gap, the economy's potential GDP, estimated using the filter developed by Hodrick and Prescott (1997), minus its actual GDP, all as a fraction of the former. Output gap measures the business cycle, growing larger when the economy is deeper in recession and smaller when the economy is more prosperous.

Regressions 6.9 through 6.12 repeat the exercise above, letting the interaction with money growth with output gap compete for explanatory power against the interaction of money growth with the state-run bank measure. Neither output gap nor its interaction with the state-run bank measure or dummy is significant in explaining either economy-level credit growth or bank- 
level credit growth. Regression 6.10 shows aggregate investment to be significantly negatively correlated with the output gap (i.e. pro-cyclical), but significantly less so if more of the banking system is state-controlled. This is consistent with investment falling off in business cycle downturns, but to a lesser degree in economies whose banking systems are more state-run, consistent with prior work (Micco and Ugo 2006; Morck et al. 2011; Lin et al. 2013; Coleman and Feler 2015) linking more state control over banks to lower business cycle amplitudes.

More importantly to our hypothesis, the interaction of money growth with the fractional importance of state-run banks remains positive and significant in explaining subsequent aggregate credit and investment growth, as does the interaction of money growth with the staterun bank dummy in the regressions explaining bank-level lending growth. That is, the baseline results are unlikely to be an artefact of state-run banks' clients' demand for credit being systematically less procyclical than that of private-sector banks' clients.

Another possibility is that state-run and private-sector banks' lending might differentially track changes in the stringency of banking regulations. If politicians or central bankers loosen banking regulations, this creates scope for banks to lend more. If political pressure then leads state-run banks to actually boost lending, the central bank might prepare for this by boosting money growth. To explore this, we define the economy-level panel variable Change in Capital Regulatory Index as annual changes in each country's capital regulatory index from Barth, Caprio and Levine (2013). This is zero (no change) for $81 \%$ of our bank-year observations, but regulatory loosening does accompany monetary expansions: its pooled simple correlation with money growth is $-0.08(p=0.01)$, though economy fixed-effects reduce the coefficient to an insignificant $0.01(p=0.39)$.

Regressions 6.13 and 6.14 in Table 6 re-estimate the baseline economy-level regressions 
4.1 and 4.2, using specifications [9a] and [9b] to let aggregate lending and capital spending rise differently upon a regulatory loosening where state-run banks are of different importance. The baseline results are unchanged: aggregate lending and capital spending rise more after a boost in money growth where state-run banks are more important. But, regulatory changes do not presage such economy-level differences. Regressions 6.15 and 6.16 revisit the bank-level baseline regressions but, using specifications [10a] and [10b], here letting changes in capital regulations presage different changes in lending by state-run versus private-sector banks. Again, the baseline results are unchanged: state-run banks boost lending after a boost to money growth; privatesector banks do not. Regression 6.15 reveals no corresponding pattern following changes in regulations, but regression 6.16 shows state-run banks boosting lending significantly more than do private-sector banks after capital regulations are relaxed. Together, regressions 6.13 through 6.16 provide mixed evidence for regulatory changes differentially affecting state-run versus private-sector bank lending. In none of these regressions do our baseline results change meaningfully. They are therefore unlikely to be driven by regulatory changes.

\subsection{State-run banks appear crucial}

State-run banks might be more prevalent where state power is broader and deeper in general. A highly interventionist government might direct its ministries, nonfinancial state-owned enterprises or politically-dependent private-sector firms to borrow and invest more, its state-run banks to lend more, which the central bank might then accommodate. If so, state-run banks are only one cog in a far-reaching apparatus of state intervention; and our baseline results regarding state-run banks should be more pronounced in economies where the overall apparatus is larger. That is, the state-run bank dummy or fractional importance variable would then matter more in 
economies whose governments are more generally highly interventionist.

To explore this, we augment the baseline regressions in yet another way. We let a measure of the reach of the state, here denoted $q_{j, t}$, also modulate the link between differences in money growth and differences in bank-credit growth. In the economy-level regressions, this entails replacing the parameter $b$ in [1] with the expression

$$
b\left(f_{j, t}\right) \equiv b_{0}+b_{1} f_{j, t}+b_{2} q_{j, t}+b_{3} q_{j, t} f_{j, t}
$$

The second and third terms on the right-hand side of [11] let the strength of the link between money growth and either aggregate credit or capital spending growth vary with the importance of state-run banking, $f_{j, t}$, and with the reach of the state, $q_{j, t}$. The final term lets the link between money growth and aggregate credit or capital spending growth vary more strongly with the importance of state-run banks if the reach of the state is greater too. Including economy fixed-effects and the main-effect of $q_{j, t}$ yields the augmented economy-level specification

[12a] $\Delta$ credit $_{j, t+1}=a_{1} f_{j, t}+a_{2} q_{j, t}+\left(b_{0}+b_{1} f_{j, t}+b_{2} q_{j, t}+b_{3} q_{j, t} f_{j, t}\right) \Delta M_{j, t}+\sum_{i} d_{j} \lambda_{j}+e_{j, t}$

$$
\operatorname{sapex}_{j, t+1}=a_{1} f_{j, t}+a_{2} q_{j, t}+\left(b_{0}+b_{1} f_{i, t}+b_{2} q_{j, t}+b_{3} q_{j, t} f_{i, t}\right) \Delta M_{j, t}+\sum_{i} d_{j} \lambda_{j}+e_{j, t}
$$

In the bank-level regressions, the analogous exercise replaces $b$ in [4] with the expression

$$
b\left(\delta_{i, j, t},\left\{x_{k, i, j, t}\right\}, q_{j, t}\right) \equiv b_{0}+b_{1} \delta_{i, j, t}+b_{2} q_{j, t}+b_{3} q_{j, t} \delta_{i, j, t}+\sum_{k} \gamma_{k} x_{k, i, j, t}
$$

Substituting [13] into [4] and including the same controls as in [6a], along with the main-effect of $p_{j, t}$ yields the augmented bank-level regressions

$$
\begin{aligned}
\text { [14a] } \Delta \text { credit }_{i, j, t+1}= & a_{1} \delta_{i, j, t}+\left(b_{0}+b_{1} \delta_{i, j, t}+b_{2} q_{j, t}+b_{3} q_{j, t} \delta_{i, j, t}+\sum_{k} \gamma_{k} x_{k, i, j, t}\right) \Delta M_{i, j, t}+ \\
& \sum_{k} c_{k} x_{k, i, j, t}+\sum_{i} d_{i} \lambda_{i}+\sum_{t} d_{t} \lambda_{t}+e_{i, j, t} \\
\text { [14b] } \Delta \text { credit }_{i, j, t+1}= & a_{1} \delta_{i, j, t}+\left(b_{1} \delta_{i, t}+b_{2} q_{j, t}+b_{3} q_{j, t} \delta_{i, j, t}+\sum_{k} \gamma_{k} x_{k, i, j, t}\right) \Delta M_{i, j, t}+ \\
& \sum_{k} c_{k} x_{k, i, j, t}+\sum_{i} d_{i} \lambda_{i}+\sum_{j, t} d_{j, t} \lambda_{j, t}+e_{i, j, t}
\end{aligned}
$$


Collecting terms and simplifying [12] and [14] reveals triple interaction terms: $b_{3}$ being the coefficient of $q_{j, t} \times f_{j, t} \times \Delta M_{j, t}$ in the economy-level regressions and of $q \times \delta_{i, j, t} \times \Delta M_{i, j, t}$ in the bank-level regressions. A significantly positive $b_{3}$ suggests that, after money growth rises, state-run banks' lending rises by more than private-sector banks' lending does where the reach of the state is greater. Thus, a significantly positive $b_{2}$ suggests that the general reach of the state matters and a significantly positive $b_{3}$ suggests that state control over banks matters more where the general reach of the state is greater. If $b_{1}, b_{2}$ and $b_{3}$ were all significantly positive, the general reach of the state might still be the predominant factor. But if $b_{1}$ remains significantly positive, its magnitude little changed from Table 4 , with $b_{2}$ and $b_{3}$ insignificant, state-run banks alone, not the reach of the state more generally, are implicated.

We set $q_{j, t}$ to each of a set of measures of the reach of state power in turn. The first, transfers and subsidies as a fraction of GDP, plausibly proxies for the size and importance of state intervention in the economy. The second, state-directed investment, defined as government investment as a share of total investment, plausibly proxies for the state's scope for directing its agencies, including stated-owned enterprises, to demand more credit and to invest more.

The third, politically connected firms, is the fraction of large businesses, by total market capitalization, run by people with personal connections to top government officials, as calculated by Faccio (2006). We interpret this as a proxy for the strength of business-government connections, and posit that more politically connected private-sector firms might be especially responsive to government directives to borrow and invest more - perhaps because they anticipate bailouts in unpropitious states (Mian and Khwaja 2005; Faccio et al. 2006).

The fourth, simple percentage of state-controlled firms, measures the importance of state ownership of business in general. This variable merges data from Faccio and Lang (2002), 
Claessens, Djankov and Lang (2000), who cover large number of firms in Europe and East Asia, respectively. Data for other countries are from La Porta, Lopez-de-Silanes and Shleifer (1999), who cover 20 largest firms in each country. All three papers provide the percentage of state controlled firms. Where more businesses are state-controlled, officials can order state-run banks to offer more credit and nonfinancial state-owned enterprises to demand more credit too. If officials ordering nonfinancial state-owned enterprises to borrow more from state-run banks helps explain our results, the increase in lending by state-run banks should be larger where stateowned enterprises are more important in general. The third and fourth measures are cross-section variables.

Table 7 summarizes the results. Thus, the bank-level tests show state-run bank lending varying no more (or less) strongly with prior money growth where the general reach of state power is greater. The point estimates change little, though the p-level in 7.4 rises to 0.14 . The economy-level regressions largely tell a similar story. The point estimates for the coefficients on money growth interacted with fraction of the banking system state-run, change little, those in 7.1 and 7.6 lose significance. In 7.1 and 7.4, additional terms are insignificant and the regression $R^{2} \mathrm{~S}$ change little, suggesting that the additional variables introduce collinearity without improving the fit. Regression 7.6, which shows aggregate capital spending changing more after money growth changes if both state-run banks and state-directed investment are more prevalent. Overall, the Table suggests that state control, whether indirect (via transfers and subsidies or political connections) or direct (state ownership) of firms that might invest more does not affect the baseline results. Rather, these tests highlight a crucial role of state-run banks lending to the private sector, rather than to state-owned or politically connected firms, though state direction of their investment might also matter. 
To explore this further, Table 8 repeats the baseline country level regressions explaining variables that measure growth in lending to and capital spending by the private sector only. Regression 8.1 explains the economy-level panel variable private sector loan growth, defined as growth in real domestic lending to the private sector, with the explanatory variables used in 4.1. Regression 8.2 similarly explains private sector investment growth, defined as growth in real gross fixed capital formation growth by the private sector. Table 1 provides detailed descriptions.

Table 8 generates results very similar to those in Table 4. Aggregate lending to the private sector and aggregate capital spending by the private sector both rise more after a boost to money growth if state-run banks are more important. Because private-sector banks do not boost lending following increases in money growth on average, these findings are inconsistent with state-run banks boosting lending only to other state-run firms.

\subsection{Other issues}

The difference between state-run and private sector banks might be different during periods of monetary expansion versus contraction. State-run banks are thought to induce an inflationary bias because their political pressure limits their ability to cut lending (Novaes and Werlang 1995). If so, political pressure might cause state-run banks to boost lending enthusiastically after money growth rises but sluggish in cutting lending amid monetary contractions.

To explore this, we consider tests (not shown) using a range of definitions of monetary expansion and contraction. This set of tests estimates a money growth trend for each economy each year by fitting a moving average process to lagged money growth. Lags ranging from four months to 18 months are used. We infer monetary policy to be expansionary or contractionary as observed money growth in the past 12 months is above or below the estimated trend. We set an 
expansion indicator variable to one if money growth is above its estimated trend and to zero otherwise. We then rerun our baseline regressions including cross-terms of the expansion indicator with money growth and with the interaction of money growth and the state run bank variable. These additional terms turn out to be quite insignificant individually and jointly, regardless of the lags we used to estimate trend money growth. These results fail to reject the hypothesis of symmetric responses in contractions and expansions. We conclude that the baseline findings reflect state-run banks both expanding their lending following expansionary monetary policy and cutting their lending following contractionary monetary policy, while private sector banks seemingly do neither.

Another issue is whether the effects we study differ between developed and developing economies. To check this, we revisit regressions of the form of [12] and [14] to see if the coefficients on the interactions of money growth with the state-run importance or indicator variable are different for developed versus developing economies. A country is classified as developed if its PPP adjusted per capita GDP at the beginning of our sample period is higher than the sample median. Tests (not shown) using a developing versus developed indicator variable to form cross-terms with the interaction between money growth and state run bank presence fail to reject the null hypothesis of equal coefficients across developed and developing economies. Additional tests (not shown) using the continuous development measure log per capita $G D P$ at purchasing power parity (PPP) exchange rates again fails to detect any significant difference in the coefficient associated with development.

\section{Political pressure appears crucial}

The previous section considered feasible alternative explanations, and excluded or substantially 
restricted each. This section presents evidence consistent with variation in likely political pressure on state-run banks explaining the differences in state-run and private-sector banks' lending change subsequent to a change in money growth. These tests further narrow the field of feasible alternative hypotheses to those with scope for variables gauging likely political pressure on state-run banks to matter. The difference between the lending growth of an individual state bank and that by an otherwise similar private-sector bank subsequent to a unit change in money growth varying with political pressure is difficult to reconcile with alternative causality scenarios.

\subsection{Politicized central banks}

The central banks of some countries are less independent - that is, more politicized - than those of other counties. A more politically sensitive central bank might let politicians order up faster money growth to encourage more lending. In contrast, an independent central bank might adjust money growth with little regard for current political priorities. If political pressure heightens state-run banks' responsiveness to money growth, such asynchronies would weaken our finding in economies with more independent central banks. This test thus further narrows the set of feasible alternative causality scenarios by ruling out those turning on state-run banks' clients credit demand being more sensitive to money growth (than is private-sector banks' clients' credit demand) for reasons unrelated to political pressure and not controlled for in our tests. If state banks clients were simply more sensitive to money growth, they would be so regardless of whether or not the central bank is independent.

To explore this, we gauge central bank independence using the measure of Crowe and Meade (2008), which ranges from zero to one, one indicating maximal independence. Table 9 
presents regressions letting differences in central bank independence modulate difference between how state-run and private-sector banks' lending growth tracks differences in money growth.

The economy-level regressions 9.1 through 9.2 show the aggregate lending result from Table 4 losing significance, but the aggregate capital spending result surviving. The bank-level regressions 9.3 and 9.4 reveal an interaction effect: if the central bank is independent, state-run banks' lending growth is insignificantly different from that of private-sector banks following increased money growth, with p-levels of 0.71 and 0.85 using the parameters and covariance matrices from 9.3 and 9.4, respectively. If the central bank is not independent, and so subject to political pressure, state-run banks' lending growth is significantly correlated with prior money growth but private-sector banks' lending is not. ${ }^{13}$

\subsection{Privatizations}

We propose that faster money growth presages boosts in state-run bank lending, but not privatesector bank lending, because civil servants in state-run banks are subject to political pressure. If little else about the banks changes upon their privatizations, we have a clean natural experiment. However, other things may well change too. For example, if the privatized bank's loan portfolio changes, changes in its lending behaviour might merely reflect its new borrowers' different credit needs. Still, the exercise is potentially useful because persistent factors such as geographical focus (Berger et al. 2005) and switching costs (Rajan 1992) plausibly deter borrowers from changing banks. Also, privatizations can be drawn-out processes, so borrowers

\footnotetext{
${ }^{13}$ The results in Table 9 survive a battery of robustness checks. Using the Alpanda and Honig's (2010) central bank de facto independence index instead to classify central banks as independent yields qualitatively similar results. Augmenting the Table 8 regressions by including the interaction of central bank independence with the statecontrolled bank dummy or fractional importance generates qualitatively similar results.
} 
wanting to switch and banks wanting to offload their nonperforming loans onto the state (Berger et al. 2005) can do so well ahead of their actual privatization dates.

These caveats in mind, we examine how the differential responsiveness of state-run banks to monetary growth changes after privatizations. ${ }^{14}$ If political pressure makes state-run bank respond more to money growth, this would disappear upon privatization. If state-run banks instead merely had different sorts of borrowers, and their loan portfolios changed little upon their privatizations, no such change in responsiveness would be evident.

We begin with a large sample of bank privatizations provided by Megginson (2005) and augment these data with more recent transactions from the Privatization Barometer and World Bank privatization transactions databases. This is necessary because our main bank-level panel includes only the largest banks in each country, and only 5 of these are privatized during our observation window. Privatization often occurs in stages, and state-run banks are sometimes incompletely privatized. We follow the literature and consider the date of the first privatization transaction (Boubakri et al. 2005) when more than $10 \%$ of the bank is transferred to private owners. If residual state ownership implies continued political pressure on lending decisions, this should work against our finding differences in the responsiveness of their lending to money growth after privatizations. We then merge these data with our BankScope and monetary base data. In this case, we only consider unconsolidated statements, because consolidation could be done with different sets of related firms before and after privatization. The sample includes only privatized banks for which data are available in the years both immediately before, $t=-1$, and immediately after, $t=+1$, the privatization year, $t=0$. Therefore our tests include two years of loan growth data for each privatization.

\footnotetext{
${ }^{14}$ We do not investigate bank nationalizations because these occur disproportionately amid financial crises.
} 
Table 10 summarizes these event study tests. Regression 10.1 explains real lending growth with money growth, an after privatization dummy, and the interaction of the two, all controlling for bank fixed-effects. Regressions 10.2 and 10.3 augment this with bank size and liquidity and their interactions with money growth, with 10.3 using stepwise estimation to introduce the additional controls, given possible multicollinearity in the small sample. All the specifications show a bank's lending ceasing (the sums of the appropriate coefficients are always insignificant) to co-vary with money growth after its privatization. The point estimates range from -0.89 to -1.06 , linking a one percentage point increase in money growth the prior year to a bit less than a percentage point lower loan growth after privatization than before privatization.

A few other results in the table merit note. First, the main-effect of money growth on loan growth is positive and significant, except in 10.2 where the full set of control variables and interactions is included. The significant coefficients indicate that a one percentage point boost to money growth over the prior year presages a 0.65 percentage point boost to state-run banks' lending growth prior to their privatizations. This affirms our baseline findings that state-run banks' lending responds significantly to monetary growth; while otherwise comparable privatesector banks' does not. Second, the sum of the regression coefficients for money growth and the cross term ranges from -0.30 to 0.37 , and is always insignificant. Thus, after privatization, a banks' credit growth does not track money growth. Third, the main-effect of the after privatization dummy, though significant in 10.2 becomes insignificant in 10.3 when control variables are introduced in a stepwise regression. This suggests that privatized banks' lending does not pick up significantly immediately after their privatizations. Loan growth might indicate new clients with different characteristics or old clients borrowing more. Even were the former the main explanation, our short observation window arguably mitigates this concern. 
In summary, privatized banks' lending no longer tracks monetary growth after their privatizations. The magnitude of this change is consistent with our baseline findings that staterun banks' lending correlates with monetary growth significantly more than does private-sector banks' lending. The timing of this change around privatizations is consistent with the end of state-control reducing this correlation. Of course, this interpretation of Table 8 depends on privatization not corresponding to an abrupt change in important characteristics of the bank's borrower clientele. Subject to this caveat, the table bolsters the case for state-run banks, but not private-sector banks, being part of the mechanism underlying pseudo-monetary policy.

\subsection{Elections}

Politicians may press harder for lending growth upon a monetary expansion if elections loom closer (Nordhaus 1975, Alesina et al. 1997, Dinc 2005). If so, our baseline results might be stronger during election campaigns than at other times. We therefore test for differences between years immediately prior to free elections (defined using an election dummy set to one if the country has a free election the subsequent year and to zero otherwise) and other years in the difference between state-run and private-sector banks' lending growth following a unit increase in money growth. To the extent that election cycles are an exogenous source of heterogeneity in political pressure on state-run banks, these tests further contribute to identification. Table 10 summarizes these tests, which are regressions of the forms [12] and [14].

Regression 10.1 shows that, in years preceding free elections, a one percentage point increase in money growth presages aggregate loan growth rising by 0.36 percentage points more in an economy whose banking system is entirely state-run than in an economy with an entirely private-sector banking system. This difference is significant $(p=0.04)$. Indeed, outside election 
years, the aggregate loan growth result loses both economic and statistical significance. Regression 10.2, shows that, in non-election years, the same unit increase in monetary growth presages a significant 1.34 percentage point higher boost to capital spending growth if the banking system is fully state-run than if it is fully private-sector. In election years, this difference rises significantly $(p=0.02)$ to $1.34+0.58=1.92$ percentage points.

Regressions 10.3 and 10.4 perform analogous exercises using bank-level data. Regression 10.4, which controls for bank and economy-year fixed-effects, shows the same unit boost to money growth in non-election years presaging a significant 0.26 percentage point larger boost to a state-run bank's lending than to lending by an otherwise similar private-sector bank in similar economic conditions. In election years, this difference rises significantly $(p=0.07)$ to $0.26+$ $0.27=0.53$ percentage points. Regression 10.3 which controls for bank and year fixed-effects, preserves the significance of the baseline result, albeit with a reduced coefficient of only 0.16 versus 0.25 in 4.6 , and reveals a positive but insignificant added difference in election years.

This evidence is predominantly (that is, except for 10.3) consistent with state-run banks more effectively transmitting money growth into increased credit and investment during election years. In other words, state-run banks respond to monetary growth more strongly when political pressure to do so is likely stronger.

\subsection{Other issues}

\section{Discussion of identification}

A series of identification tests successively pare away alternative causality scenarios to leave pseudo-monetary policy the most plausible and parsimonious explanation of these findings. Our firm-level regressions can be interpreted as difference-in-difference tests, showing a difference in 
money growth leading different differences in lending growth for state state-run versus privatesector banks of similar size and liquidity in the same economies and years. This precludes macroeconomic reverse causality scenarios (e.g. credit demand shifts causing money growth and bank lending) that cannot explain why only state-run bank lending responds. ${ }^{15}$

Bank fixed-effects preclude alternative causality scenarios driven by any time-invariant bank-level (e.g. historical bank characteristics, etc.) or economy-level (e.g. legal origin, etc.) latent factors. Economy-year fixed effects preclude alternative causality scenarios driven by any time-varying economy-level latent factors (e.g. the general importance of state-owned enterprises, etc.) or their interactions with money growth (these interactions are also timevarying economy-level variables).

Such latent factors could only have traction if they have potential to affect state-run and private-sector banks differently. Examples of variables with such potential include exchange rate depreciations, fiscal expansions or business cycle variables, which might increase credit demand at state-run banks relative to private-sector banks if state-run banks disproportionately financed exports, infrastructure projects, or relatively recession-proof government-connected sectors, respectively. Tests directly incorporating these and other such variables continue to show changes in money growth presaging changes in state-run bank lending.

Alternative causality scenarios in which state-run banks are more important in countries with more generally interventionist governments are also considered. For example, state-run bank lending might rise because demand for credit by nonfinancial state-owned enterprises or

\footnotetext{
${ }^{15}$ Other approaches to identification in bank lending (e.g. Puri et al. 2011; Jiménez et al. 2014) use loan-level application and credit data. Unfortunately, comparable data for enough countries and years to be of use in this context are not presently available. Moreover, because observable loan transactions are presumably made where the demand and supply curves cross, distinguishing demand from supply effects must depend on additional assumptions.
} 
politically-connected firms rises following a boost to money growth. Again, our results are not affected by directly incorporating a series of variable measuring the reach of the state into our tests. Rather, additional tests show faster money growth presaging faster credit to the private sector and faster capital spending by the private sector in economies with more predominantly state-run banking systems.

Finally, a series of tests show our results to be stronger where political pressure is stronger on state-run banks to boost lending following a boost to money growth. Our baseline results are stronger when money growth precedes an election and where the central bank is less independent, letting money growth and state-run bank lending better respond to political pressure together. Additional tests on a sample of privatized banks show their lending moving in step with money growth until their privatizations and then entirely ceasing to do so after their privatizations.

While no single one of these identification tests is bulletproof, their combined results weigh strongly against alternative causality scenarios and in favour of a pseudo-monetary policy effect. Faster money growth, perhaps reflecting political pressure on the central bank, lets banks lend more; political pressure makes state-run banks lend more. Thus, faster money growth presages both faster loan growth by state-run banks and faster aggregate credit and capital spending growth by economies whose banking sectors are more state-run.

\section{Reconciliation of Conflicting Country Studies}

This finding reconciles seemingly discordant results in prior studies using data from individual countries. Deng et al. (2014) report China's state-run banks boosting lending after money growth increased amid the 2008 financial crisis; however, Das et al (2015) find India's ineffective and 
undisciplined civil service. India's civil service is shown elsewhere to be profoundly dysfunctional (Das 2005; Mathur 2014). Although China is not in our sample, its civil servants are shown elsewhere to be both highly effective (Burns 2004) and highly responsive to political direction (MacGregor 2010). This reasoning suggests that our baseline findings might differ with civil service characteristics.

To explore this, we run regressions (not shown) as in Table 7s, but replacing central bank independence with the product of measures of the political sensitivity and effectiveness of each economy's civil service. ${ }^{16}$ The baseline results are preserved, but the bank-level regressions show individual state-run banks boosting lending by a significantly greater margin where civil servants are rated as both more effective and more sensitive. The pseudo-monetary policy transmission channel we posit might thus work more effectively where government officials are more effective and politically disciplined. However, we are reluctant to press this interpretation as no corresponding significant differences are evident in the economy level regressions. We welcome additional research into these issues.

\section{Conclusions}

A command and control channel appears to connect money growth to the real economy via staterun banks. Money growth changes, perhaps reflecting political pressure on the central bank, and state-run banks then change their lending because politicians order them to. Because this mechanism entails a monetary expansion being transmitted to the real economy via increased

\footnotetext{
${ }^{16}$ A country's civil service is called effective if its government effectiveness index (Kaufmann, Kraay and Mastruzzi, 2010) exceeds its sample median. A country's civil service is called sensitive to political pressure if the average response to two survey questions (Q8.b and Q8.e) in the Quality of Government Expert Survey Dataset (Teorell, Dahlström and Dahlberg, 2011) exceeds its sample median. The two questions ask experts to evaluate how fully public sector employees strive to implement (1) the ideology of the party/parties in power, and (2) the policies of the top political leadership.
} 
bank lending to the private sector, it is properly considered a variant of monetary policy. However, because it operates via political pressure rather than via microeconomics, it differs fundamentally from standard monetary policy transmission channels. We therefore term this phenomenon pseudo-monetary policy.

We find that pseudo-monetary policy is statistically and economically significant in many economies. At the bank level, faster money growth precedes faster loan growth by state-run banks than by private-sector banks. At the economy-level, faster money growth precedes faster bank credit growth and capital investment growth by greater margins (both in total and in the private sector alone) in economies whose banking systems are more fully state-run, but does not precede either in economies whose large banks are entirely private-sector. A battery of robustness and identification tests leave pseudo-monetary policy the most parsimonious and plausible explanation of these findings.

The seeming efficacy of pseudo-monetary policy suggests that differences between staterun and private-sector banks are important in this context. One key difference is in their respective objective functions. Private-sector banks are in business to maximize firm value; state-run banks have the additional business to advance politicians' public policy goals (La Porta et al. 2002, 2003; Sapienza 2004; Dinc 2005, Deng et al. 2011; Mian and Khwaja 2011; Morck et al. 2011). Both act within regulatory and budget constraints, the latter perhaps softer for staterun banks (Kornai et al. 2003). Both pursue these objectives imperfectly because their top insiders also maximize their utility (Jensen and Meckling 1976).

State-run bank governance may differ across countries, but their senior executives tend to be either career civil servants or political appointees. In either case, attending to political priorities affects their careers and thus enters their utility calculations. India's state-run 
commercial banks have always been run by political appointees, though the bank of Baroda made headlines in 2015 by appointing P.S. Jayakumar of Citibank its CEO (Bandyopadhyay 2018). ${ }^{17}$ China's state-run bank top executives, always career Party cadres, are compensated annually for bank accounting performance, but their careers are in the hands of the Communist Party of China, via its Organization Department. Their harmonious implementation of Party policies critically affects their being promoted, demoted or reassigned to a new position (Deng et al. 2014). The tiny Bank of North Dakota, the only state-run commercial bank in the United States, has generally been run by ex-politicians and political advisors, though its current CEO, Eric Hardmeyer, rose up through the ranks internally.

We posit that pseudo-monetary policy operates effectively because state-run banks' directors and officers are public servants, whose careers depend on implementing politicians' formal policy directives and informal "jawboning" requests (Shleifer and Vishny 1994). Money growth suffices to let bank lending to expand; political pressure necessitates that they do so. This straightforward mechanism contrasts with conventional monetary policy transmission channels, surveyed by Mishkin (1996), which contain chains of causality whereby money growth ultimately may affect how private-sector banks' lending decisions affect their valuations or other objective functions. We welcome further work exploring whether more nuanced differences in the governance of state-run banks might affect their effectiveness in pseudo-monetary policy transmission, and exploring whether political connections might also mobilize private-sector banks in some cases.

Prior to the 2008 financial crisis, many macroeconomics researchers had concluded (Rasche and Williams 2007, p. 490) that "the case for consistently effective short-run monetary

\footnotetext{
${ }^{17}$ Canara Bank also appointed a CEO with private-sector experience in 2015, though Rakesh Sharma had worked at the State Bank of India for three decades before moving to the private-sector.
} 
stabilization policies is problematic" and relegated central bankers to inflation targeting (Goodfriend 2007; Mishkin 2011). The so-called Great Moderation in many OECD countries' business cycles from the mid-1980s through 2006 seemingly validated Taylor's (2016) supposition that "the real world will take care of itself." The various channels through which monetary policy might buffer recessions seemed to work poorly if at all.

Yet politicians and central bankers never completely abandon the monetary stimulation option. The U.S. Federal Reserve Open Markets Committee justified a monetary expansions after the 1987 market crash "to cushion the effects on prospective economic growth, to counter the "Y2K" scare about widespread computer failures in January $1^{\text {st }} 2000$, and after the " $9 / 11$ " terrorist attacks to counter "heightened uncertainty and concerns about a deterioration in business conditions both here and abroad damping economic activity" (Rasche and Williams 2007). As the 2008 financial crisis unfolded the academic consensus weakened (Caballero 2010; Mishkin 2011) and central bankers oversaw unprecedented monetary expansions (Mishkin 2009; Claessens et al. 2010; Bernanke 2012), even as benchmark interest rates fell into the zero-lower bound zone, where even neo-Keynesians thought monetary policy ineffective (Tobin 1947; Abbassi and Linzert 2012). Regardless of the theories and empirical evidence, politicians and central bankers (voluntarily or pressed) felt they needed to "do something"; and monetary expansion was "something" therefore so they needed to do it.

Pseudo-monetary policy may thus present a chancy political temptation. State-run banks' lending constitutes less efficient capital allocation than does lending by private-sector banks ( $\mathrm{La}$ Porta, et al. 2002, 2003; Morck et al. 2011), and inefficient capital allocation imposes long-run barriers to economic growth (Levine and King 1993; Rajan and Zingales 1998; Wurgler 2000). A social welfare trade-off thus plausibly exists, with more state-run banks mitigating short-run 
welfare losses from business cycles but aggravating long-run costs of capital misallocation. Because myopia can distort self-interested politicians" priorities (Nordhaus 1975; Alesina et al. 1997; Dinc 2005; Micco et al. 2007), government policy might compromise social welfare by making excessive use of such a command and control stimulus channel. 


\section{References}

Abbassi, Puriya and Tobias Linzert. 2012. The effectiveness of monetary policy in steering money market rates during the financial crisis. Journal of Macroeconomics 34(4)945-954.

Acharya, V. 2015. Financial stability in the broader mandate for central banks: A political economy perspective. Brookings Hutchins Center working paper (April 2015).

Adolph, Christopher. 2013. Bankers, bureaucrats, and central bank politics: The myth of neutrality. Cambridge University Press.

Alesina, A., Roubini, N., and Cohen, G., 1997. Political cycles and the macroeconomy, Cambridge, MA: MIT Press.

Almeida, H. and Wolfenzon, D., 2006. Should business groups be dismantled? The equilibrium costs of efficient internal capital markets. Journal of Financial Economics 79, 99-144.

Alpanda, S, and Honig, A., 2010. Political monetary cycles and a de facto ranking of central bank independence. Journal of International Money and Finance 29, no. 6: 1003-1023.

Bandyopadhyay, Tamal. 2018. How public sector bank CEOs are selected. Livemint.com 25 January 2018.

Barth, J.R., Caprio Jr, G. and Levine, R., 2013. Bank Regulation and Supervision in 180 Countries from 1999 to 2011. Journal of Financial Economic Policy, 5(2), pp.111-219.

Beck, T., Clarke, G., Groff, A., Keefer, P, and Walsh, P., 2001. New tools in comparative political economy: The database of political institutions. 15:1, 165-176, World Bank Economic Review.

Berger, A. N., Clarke, G. R., Cull, R., Klapper, L., \& Udell, G. F. ,2005. Corporate governance and bank performance: A joint analysis of the static, selection, and dynamic effects of domestic, foreign, and state ownership. Journal of Banking \& Finance, 29(8), 2179-2221.

Bernanke, Ben S. 2012. Opening remarks: monetary policy since the onset of the crisis. The Changing Policy Landscape, Economic Policy Symposium, Federal Reserve Bank of Kansas City, Jackson Hole, Wyoming.

Bertay, A.C., Demirgüç-Kunt, A. and Huizinga, H., 2015. Bank ownership and credit over the business cycle: Is lending by state banks less procyclical?. Journal of Banking \& Finance, 50, pp.326-339.

Blinder, Sarah and Mark Spindel. 2017. The Myth of Interdependence How Congress Governs the Federal Reserve. Princeton University Press.

Boubakri, N., Cosset, J. C., Fischer, K., \& Guedhami, O., 2005. Privatization and bank performance in developing countries. Journal of Banking \& Finance, 29(8), 2015-2041.

Bouis, R.,Rawdanowicz, Ł., Renne, J., Watanabe, S., and Christensen, A.K., 2013. The effectiveness of monetary policy since the onset of the financial crisis. Economics Department working paper No. 1081 (ECO/WKP(2013)73). Organisation for Economic Co-operation and Development.

Brei, Michael and Alfredo Schclarek. 2013. Public bank lending in times of crisis. Journal of Financial Stability 9(4)820-830.

Brei, Michael, and Alfredo Schclarek. 2015. A theoretical model of bank lending: Does ownership matter in times of crisis? Journal of Banking \& Finance 50, 298-307.

Burns, John. 2004 Governance and Civil Service Reform. In Jude Howell, ed. Governance in China, pp. 37-57. Rowman Littlefield.

Bushman R.M. and Williams, C. D., 2012. Accounting discretion loan loss provisioning, and discipline of bank's risk-taking. Journal of Accounting and Economics 54, 118.Bushman, R.M. and Williams, C.D., 2015. Delayed expected loss recognition and the 
risk profile of banks. Journal of Accounting Research, 53(3), pp.511-553.

Caballero, R. J., 2010. Macroeconomics after the Crisis: Time to deal with the pretense-ofknowledge syndrome. Journal of Economic Perspectives 24(4) 85-102.

Caballero, Ricardo J. 2010. Macroeconomics After the Crisis: Time to Deal with the Pretense-ofKnowledge Syndrome." Journal of Economic Perspectives 24(4)85-102

Caldarola, C., 1979. The Social Credit in Alberta, 1935 - 1971. In Carlo Caldarola, ed. Society and Politics in Alberta: Research Papers, c3, 33-48. Taylor \& Francis.

Calomiris, Charles \& Stephen H. Haber. 2015. Fragile by design: The political origins of banking crises and scarce credit. Princeton University Press.

Campello, M., 2002, Internal capital markets in financial conglomerates: Evidence from small bank responses to monetary policy, Journal of Finance 57(6), 2773-2805.

Caprio, G., Laeven, L., Levine, R., 2007. Governance and bank valuation. Journal of Financial Intermediation 16, 584-617

Carvalho, D. 2014. The Real Effects of Government-Owned Banks: Evidence from an emerging market. Journal of Finance, 69(2), 577-609.

Cetorelli, N. and Goldberg, L.S., 2012. Banking globalization and monetary transmission. The Journal of Finance, 67(5), pp.1811-1843.

Chakraborty, I., Goldstein, I., and MacKinlay, A., 2015. Monetary stimulus and bank lending. Working paper.

Claessens, Stijn, Giovanni Dell'Ariccia, Deniz Igan, and Luc Laeven. 2010. Cross-country experiences and policy implications from the global financial crisis. Economic Policy 25(62)267-293.

Coleman, N. and Feler, L., 2015. Bank ownership, lending, and local economic performance in the 2008 Financial Crisis. Journal of Monetary Economics, Volume 71, 50-66

Crowe, C., \& Meade, E. E. (2008). Central bank independence and transparency: Evolution and effectiveness. European Journal of Political Economy, 24(4), 763-777.

Das, A., Mishra, P., and Prabhala N.,2015. The transmission of monetary policy within Banks: Evidence from India, working paper, CAFRAL.

Das, S.K. 2005 Public Office, Private Interest: Bureaucracy and Corruption in India. Oxford University Press

Deng, Y., Morck, R., Wu, J., and Yeung, B., 2011. Monetary and fiscal stimuli, ownership structure and China's housing market. Forthcoming, Review of Finance.

Dinc, S., 2005. Politicians and Banks: Political influences on government-owned banks in emerging markets, Journal of Financial Economics, 77, 453-479.

Eslava, M. 2011. The Political Economy of Fiscal Deficits: A Survey. Journal of Economic Surveys 25(4)645-673.

Faccio, M., 2006. Politically connected firms. American Economic Review 369-386.

Fischer, Stanley, 1988, Recent Developments in Macroeconomics, Economic Journal, Vol. 98, No. 391, pp. 294-339, (June)

Fleming, J. Marcus. 1962. Domestic financial policies under fixed and under floating exchange rates. Staff Papers, International Monetary Fund, Vol. 9 (November), pp. 369-79.

Froot, K. A. and J. C. Stein, (1991), "Exchange rates and foreign direct investment: an imperfect capital markets approach," Quarterly Journal of Economics, Nov 1991, pp. 1190- 1217.

Gambacorta, L., and Mistrulli, P. E., 2004. Does bank capital affect lending behaviour?, Journal of Financial Intermediation 13.

Goodfriend, Marvin. 2007. How the World Achieved Consensus on Monetary Policy,” Journal 
of Economic Perspectives 21(4)47-68.

Hodrick, R., Prescott, E., 1997. Postwar US business cycles: An empirical investigation. Journal of Money Credit and Banking 29, 1-16

Ivashina, V. and Scharfstein, D. 2010. Bank lending during the financial crisis of 2008. Journal of Financial Economics 97(3)319-338

Jiménez, G., Ongena, S., Peydró, J.L. and Saurina, J., 2014. Hazardous Times for Monetary Policy: What Do Twenty-Three Million Bank Loans Say About the Effects of Monetary Policy on Credit Risk-Taking?. Econometrica, 82(2), pp.463-505.

Kashyap, A. K., and Stein J. C., 2000. What do a million observations on banks say about the transmission of monetary policy? American Economic Review 90.

Kaufmann, Daniel, Kraay, Aart and Mastruzzi, Massimo,2010. The worldwide governance indicators: Methodology and analytical issues. World Bank policy research working paper No. 5430.

La Porta, R., Lopez-de-Silanes, F., Shleifer, A., 2002. Government ownership of banks. Journal of Finance 57, 265-301.

La Porta, R., Lopez-de-Silanes, F., Shleifer, A., and Vishny, R. 1999. The quality of government. Journal of Law, Economics, and Organization 15, no. 1: 222-279.

La Porta, R., Lopez-De-Silanes, F., Zamarripa, G., 2003. Related lending. Quarterly Journal of Economics 118, 231-268.

Laeven, L., Levine, R., 2009. Bank governance, regulation and risk taking. Journal of Financial Economics 93, 259-275.

Lin, Y., Srinivasan, A., and Yamada, T, 2013. The bright side of lending by government owned banks: Evidence from the financial crisis in Japan. University of Adelaide working paper.

Lucas, R. E. ,1987. Models of business cycles (Vol. 26). Oxford: Basil Blackwell.

Lucas, R. E. 1972. Expectations and the neutrality of money. Journal of Economic Theory 4(2)103-24.

Mathur, B.P. 2014. Ethics for Governance: Reinventing Public Services. Routledge

McGregor, Richard. 2010. The Party: The Secret World of China's Communist Rulers. HarperCollins.

Megginson W., 2005. The financial economics of privatization. First edition, New York: Oxford University Press.

Mian, A., and Khwaja, A.I., . 2005. Do lenders favor politically connected firms? Rent provision in an emerging financial market. Quarterly Journal of Economics 120(4)

Micco, A., Panizza, U. and Yanez, M., 2007. Bank ownership and performance. Does politics matter? Journal of Banking \& Finance, 31(1), pp.219-241.

Micco, A., Panizza, U., 2006. Bank ownership and lending behavior. Economic Letters 93 24854.

Mishkin, F.S., 1996. The channels of monetary transmission: Lessons for monetary policy. NBER working paper. No 5464.

Mishkin, Frederic S. 2009. Is Monetary Policy Effective during Financial Crises? American Economic Review 99(2)573-577.

Mishkin, Frederic S. 2011. Monetary policy strategy: lessons from the crisis. National Bureau of Economic Research working paper 16755.

Morck, R., Wolfenzon, D., Yeung, B., 2005. Corporate governance, economic entrenchment, and growth. Journal of Economic Literature 43, 655-720

Morck, R., Yavuz, M. D., Yeung, B., 2011. Banking system control, capital allocation, and 
economy performance. Journal of Financial Economics 100, 264-283

Mundell, R. A., 1963, Capital mobility and stabilization policy under fixed and flexible exchange-rates, Canadian Journal of Economics \& Political Science 29.

Nordhaus, W., 1975. The political business cycle. Review of Economic Studies 42(2)169-190.

Novaes, Walter, and Sergio Werlang. 1995. Inflationary bias and state-owned financial institutions. Journal of Development Economics 47(1)135-154.

Petersen, M., 2009. Estimating standard errors in finance panel data sets: Comparing approaches. Review of Financial Studies 22 (1)

Puri, M., Rocholl, J. and Steffen, S., 2011. Global retail lending in the aftermath of the US financial crisis: Distinguishing between supply and demand effects. Journal of Financial Economics, 100(3), pp.556-578.

Rajan, R. 1992. Insiders and outsiders: The choice between informed and arm's-Length debt. Journal of Finance 47(4)1367-1400.

Rajan, Raghuram G., and Luigi Zingales. 1998. Financial Dependence and Growth. American Economic Review 88(3)559-586.

Rasche, Robert and Marcela Williams. 2007. The effectiveness of monetary policy. Federal Reserve Bank of St. Louis Review 2007(Sept.)447-490.

Samuelson, P., 1939. Interactions between the multiplier analysis and the principle of acceleration, Review of Economic Statistics, 21, 75-8.)

Sapienza, P., 2004. The effects of government ownership on bank lending. Journal of Financial Economics 72.

Stiglitz, J. 2012. A Revolution in Monetary Policy: Lessons in the Wake of the Global Financial Crisis, C.D. Deshmukh Memorial Lecture, Reserve Bank of India, Mumbai.

Taylor, John B., 2016. Central Bank Models: Lessons from the Past and Ideas for the Future, Keynote Presentation at the Workshop "Central Bank Models: The Next Generation," Bank of Canada, November 17.

Teorell, J. , Dahlström C. and Dahlberg, S. 2011. The QoG Expert Survey Dataset. University of Gothenburg: The Quality of Government Institute.

Tobin, James. 1947. Liquidity preference and monetary policy. Review of Economics and Statistics 29 (2)124-31. 


\section{Table I: Variable definitions and sources}

\section{Panel A: Variables reflecting state control over banks}

State-run bank Bank-year annual panel indicator variable set to 1 if the bank has a state organ as ultimate indicator controlling shareholder. Control is imputed to the largest blockholder whose voting control, direct and indirect, sum to at least $10 \%$. Indirect control is inferred using the "weakest link" method (La Porta et al. 1999).

Fraction of Economy-level annual panel of the lagged credit-weighted fractions of banks with a state organ as banking system ultimate controlling shareholder. Ultimate control is as in the definition of the bank-level indicator state-run state-run.

\section{Panel B: Main monetary policy and outcome measures}

Growth in Economy-year panel of annual real growth rate of gross fixed capital spending, (capex $x_{t+1}-$ capital spending cape $\left.x_{t}\right) /$ cape $_{t}$ and winsorized at $10 \%$ level over the full panel. Gross fixed capital spending is seasonally adjusted total value of producers' acquisitions, less disposals, of fixed assets plus certain additions to the value of non-produced assets (e.g. subsoil assets or major improvements in the quantity, quality, or productivity of land), deflated by the producer price index. Source: IMF International Financial Statistics (IFS) Database: National Accounts and Population, Gross Fixed Capital Spending (line 93e).

Growth in Economy-year panel of real growth rates of domestic credit provided by banking sector. Aggregate lending loans are defined as domestic credit provided by banking sector over GDP from WDI times GDP in (economy-level) current local currency. Each country's CPI index is used to deflate nominal aggregates. The growth rate is winsorized at $10 \%$ level within the entire panel. Source: WDI.

Growth in Bank-year panel of real growth rates in gross loans, i.e. (gross loans t $+1_{1}-$ gross loans $_{t}$ )/ lending gross loans $s_{t}$, deflated using the consumer price index and winsorized at $10 \%$ within the entire (bank-level) panel. If gross loans are missing net loans are used. Source: BankScope.

Money growth Economy-year panel of nominal monetary base growth during the last 12 months of the prior year, (monetary base $_{t}-$ monetary base $_{t-1}$ ) / monetary base $e_{t}$ winsorized at the $10 \%$ level within entire panel. We take seasonally adjusted values from either the reporting country or the IMF, if available; and otherwise run a rolling regression for 5 prior years of money growth on quarter dummies to calculate seasonal adjusted values. Euro-zone countries are considered one economy in calculating this variable after adoption of the euro. Source: IMF International Financial Statistics (IFS) Database, Central Bank Survey, section 10, country table line 14.

\section{Panel C: Other variables}

Central bank independence

Exchange rate depreciation

Fiscal stimulus
Crowe and Meade's (2008) independence index reflecting appointment procedures for head of central bank, resolution of conflict between central bank and executive branch, existence of explicit policy target, and rules limiting lending to government. The index is cross-sectional.

Percent change in the exchange rate measured as local currency in US dollar, over the prior 12 months. A more positive value implies more local currency depreciation against the U.S. dollar. Source: IMF Financial Statistics.

Economy-level panel of changes in fiscal balance during the prior 12 month, as a fraction of the prior years' year-end nominal GDP. Sources: Government surplus or deficit data are from DataStream (DS Mnemonic =.govbala), and supplemented with IMF GFS data on either net operating balances or net lending. These variables are calculated on accounting or cash bases and for the overall government, central government, or budgetary central government; and we take data as available in those orders of priority. Net operating balances (line anob) are revenue (a1) less expenses (a2). Revenues includes taxes, social contributions, grants and other revenues; expenses include compensation of employees, use of goods and services, consumption of fixed capital, interest, subsidies, grants, social benefits and other expenses (GFSM manual 2001). Net cash inflow from operating activities (ccio) is cash receipts (c1) less payments for (c2) operating 
activities. Net lending/borrowing (anlb) is net operating balance (anob) less net acquisition of nonfinancial assets (a31). The cash equivalent, the cash surplus/deficit (ccsd), is net cash inflow from operating activities (ccio) less net cash outflow from investments in nonfinancial assets (c31).

Foreign- Bank-year panel dummy set to 1 if the bank is a subsidiary of a foreign bank. Constructed controlled analogously to State.

PoliticallyEconomy-level cross section variable measuring politically connected firms as percent of market connected firms capitalization. Source: Faccio (2006).

GDP Growth GDP growth in constant local currency lagged by one year. GDP growth is calculated as [GDP (t)GDP(t-1)]/GDP(t-1). Source: World Bank national accounts, OECD National Accounts.

State-directed Economy-level panel data of lagged annual government investment as a share of total investment. investment Source Economic Freedom of the World Index.

State-controlled Economy-level cross sectional variable measuring percent of firms that are state-owned enterprises.

firms

Bank liquidity Bank-year panel variable equal to the bank's previous year-end ratio of government securities plus cash and amounts due from banks to total assets. Source: BankScope.

Output gap Potential GDP less actual GDP, as a percent of potential GDP, all lagged one year. Potential GDP is estimated using the filter developed by Hodrick and Prescott (1997) using past annual GDP growth, with the smoothing parameter of 6.25 they suggest for annual GDP data.

Bank size Bank-year panel variable equal to prior fiscal year-end log total assets in USD. Source: BankScope

Transfers and Economy-level panel data of lagged annual measure of general government transfers and subsidies subsidies as a share of GDP. Source Economic Freedom of the World Index.

Election years Dummy variable set to one if the country will hold a free election the next year and to zero otherwise. Election dates (presidential elections for presidential systems and parliamentary elections for parliamentary and assembly-elected presidential systems are from the International Institute for Democracy and Electoral Assistance (IDEA) database. The system in effect in each country each year is from the World Bank Database of Political Institutions (Beck et al., 2001). The variable is zero for elections (or countries) classified as "not free" by Freedom House.

Change in Change in bank capital requirement stringency index, as provided by Barth, Caprio and Levine capital (2013) over the prior twelve months. Increases in the index indicate increased capital regulatory index requirements.

Private sector Growth in real domestic lending to the private sector is growth in domestic credit to private sector loan growth by banks (obtained from WDI as percent of GDP and multiplied by current LCU GDP), deflated by the economy's consumer price index and winsorized at $10 \%$.

Private sector Real gross fixed capital formation growth by the private sector is annual growth rate in gross fixed investment growth capital formation, private sector (current LCU), from WDI. deflated by the economy's producer price index and winsorized at $10 \%$ 
Table II: Economy-level descriptive statistics of main variables

\begin{tabular}{|c|c|c|c|c|c|c|c|}
\hline \multirow[t]{2}{*}{ Economy } & \multicolumn{2}{|c|}{ Money growth } & \multicolumn{2}{|c|}{ Growth in lending } & \multicolumn{2}{|c|}{$\begin{array}{l}\text { Growth in capital } \\
\text { spending }\end{array}$} & \multirow{2}{*}{$\begin{array}{c}\text { Fraction of } \\
\text { banking system } \\
\text { state-run }\end{array}$} \\
\hline & Mean & $\sigma$ & Mean & $\sigma$ & Mean & $\sigma$ & \\
\hline Argentina & 0.212 & 0.083 & 0.041 & 0.102 & 0.061 & 0.095 & 57 \\
\hline Austria & 0.112 & 0.090 & 0.070 & 0.096 & -0.007 & 0.045 & 0 \\
\hline Brazil & 0.063 & 0.061 & 0.097 & 0.117 & 0.026 & 0.023 & 43 \\
\hline Canada & 0.037 & 0.017 & 0.049 & 0.080 & 0.033 & 0.064 & 0 \\
\hline Colombia & 0.181 & 0.031 & 0.112 & 0.084 & 0.078 & 0.073 & 13 \\
\hline Denmark & 0.088 & 0.087 & 0.094 & 0.113 & -0.007 & 0.060 & 0 \\
\hline Egypt & 0.207 & 0.117 & 0.010 & 0.121 & 0.065 & 0.129 & 94 \\
\hline Finland & 0.144 & 0.096 & 0.085 & 0.142 & NA & NA & 0 \\
\hline France & 0.112 & 0.086 & 0.084 & 0.101 & 0.023 & 0.038 & 12 \\
\hline Germany & 0.107 & 0.089 & 0.041 & 0.108 & -0.013 & 0.042 & 25 \\
\hline Greece & 0.162 & 0.083 & 0.139 & 0.112 & 0.015 & 0.105 & 79 \\
\hline Hong Kong & 0.112 & 0.089 & 0.078 & 0.098 & NA & NA & 3 \\
\hline India & 0.155 & 0.062 & 0.172 & 0.073 & NA & NA & 100 \\
\hline Indonesia & 0.156 & 0.075 & 0.140 & 0.105 & 0.084 & 0.048 & 93 \\
\hline Ireland & 0.141 & 0.074 & 0.145 & 0.115 & 0.004 & 0.081 & 0 \\
\hline Israel & 0.013 & 0.032 & 0.011 & 0.068 & -0.002 & 0.054 & 56 \\
\hline Italy & 0.148 & 0.077 & 0.085 & 0.085 & -0.011 & 0.059 & 0 \\
\hline Japan & 0.049 & 0.062 & 0.000 & 0.052 & -0.031 & 0.040 & 20 \\
\hline Jordan & 0.093 & 0.074 & 0.099 & 0.109 & NA & NA & 7 \\
\hline Kenya & 0.102 & 0.037 & 0.076 & 0.094 & NA & NA & 73 \\
\hline Korea & 0.084 & 0.093 & 0.087 & 0.087 & 0.033 & 0.058 & 53 \\
\hline Malaysia & 0.076 & 0.038 & 0.069 & 0.052 & 0.025 & 0.075 & 6 \\
\hline Mexico & 0.141 & 0.038 & 0.061 & 0.144 & 0.043 & 0.075 & 0 \\
\hline Netherlands & 0.145 & 0.079 & 0.039 & 0.076 & 0.004 & 0.076 & 26 \\
\hline Norway & 0.172 & 0.097 & 0.079 & 0.040 & 0.030 & 0.107 & 59 \\
\hline Pakistan & 0.123 & 0.051 & 0.126 & 0.115 & NA & NA & 93 \\
\hline Peru & 0.127 & 0.084 & 0.074 & 0.142 & 0.082 & 0.062 & 12 \\
\hline Philippines & 0.175 & 0.100 & 0.049 & 0.131 & 0.002 & 0.074 & 6 \\
\hline Portugal & 0.132 & 0.091 & 0.086 & 0.073 & NA & NA & 10 \\
\hline Singapore & 0.094 & 0.076 & 0.048 & 0.064 & NA & NA & 42 \\
\hline South Africa & 0.152 & 0.013 & 0.087 & 0.127 & 0.090 & 0.083 & 0 \\
\hline Spain & 0.134 & 0.086 & 0.118 & 0.114 & 0.029 & 0.074 & 10 \\
\hline Sri Lanka & 0.137 & 0.030 & 0.048 & 0.106 & NA & NA & 58 \\
\hline Sweden & 0.048 & 0.087 & 0.072 & 0.075 & 0.023 & 0.073 & 0 \\
\hline Switzerland & 0.046 & 0.065 & 0.039 & 0.085 & 0.015 & 0.031 & 29 \\
\hline Thailand & 0.087 & 0.053 & 0.017 & 0.078 & 0.021 & 0.070 & 51 \\
\hline Turkey & 0.251 & 0.027 & 0.146 & 0.103 & 0.035 & 0.093 & 22 \\
\hline United Kingdom & 0.174 & 0.103 & 0.046 & 0.112 & -0.001 & 0.099 & 0 \\
\hline United States & 0.074 & 0.080 & 0.041 & 0.120 & -0.021 & 0.046 & 0 \\
\hline Venezuela & 0.224 & 0.112 & 0.070 & 0.179 & 0.061 & 0.095 & 0 \\
\hline
\end{tabular}

Economy-level means and standard deviations of key variables for $2001-2011$. Money growth is prior 12 month monetary base growth. Annual loan growth is economy-level mean of bank-level data. Money growth, loan growth and capex growth are winsorized at $10 \%$. Variables are defined in Table 1. 


\section{Table III. Simple correlations}

Sample for Panel A is annual data for the 40 economies listed in Table 1 from 2001 to 2011. However, the sample changes with the availability of variables. For example, correlations with growth in capital spending are calculated for the 30 countries for which this variable is available. Sample for Panel B is annual data form the largest banks in each of the 40 economies over the same years. Numbers in the second row are $p$-levels adjusted for clustering at the economy-level in Panel A and the bank-level in Panel B. Boldface indicates significance at $10 \%$ or better. Variables are defined in Table 1.

Panel A. Country-level variables

\begin{tabular}{|c|c|c|c|c|}
\hline & $\begin{array}{c}\text { Growth in } \\
\text { lending }\end{array}$ & $\begin{array}{c}\text { Growth in capital } \\
\text { spending }\end{array}$ & $\begin{array}{l}\text { Money } \\
\text { growth }\end{array}$ & $\begin{array}{c}\text { Fraction of banking } \\
\text { system state-run }\end{array}$ \\
\hline $\begin{array}{c}\text { Growth in } \\
\text { capital spending }\end{array}$ & $\begin{array}{c}0.16 \\
(0.09)\end{array}$ & & & \\
\hline Money growth & $\begin{array}{c}0.05 \\
(0.47)\end{array}$ & $\begin{array}{l}-0.03 \\
(0.78)\end{array}$ & & \\
\hline $\begin{array}{l}\text { Fraction of banking } \\
\text { system state-run }\end{array}$ & $\begin{array}{l}-0.12 \\
(0.29)\end{array}$ & $\begin{array}{c}0.25 \\
(0.00)\end{array}$ & $\begin{array}{c}0.02 \\
(0.72)\end{array}$ & \\
\hline Interest rate drop & $\begin{array}{c}0.01 \\
(0.83)\end{array}$ & $\begin{array}{l}-0.24 \\
(0.01)\end{array}$ & $\begin{array}{c}0.02 \\
(0.81)\end{array}$ & $\begin{array}{l}-0.19 \\
(0.00)\end{array}$ \\
\hline $\begin{array}{l}\text { Private sector } \\
\text { loan growth }\end{array}$ & $\begin{array}{c}0.73 \\
(\mathbf{0 . 0 0})\end{array}$ & $\begin{array}{c}0.44 \\
(0.00)\end{array}$ & $\begin{array}{l}-0.01 \\
(0.84)\end{array}$ & $\begin{array}{c}0.08 \\
(0.45)\end{array}$ \\
\hline $\begin{array}{c}\text { Private sector } \\
\text { investment growth }\end{array}$ & $\begin{array}{c}0.26 \\
(0.01)\end{array}$ & $\begin{array}{c}0.79 \\
(0.00)\end{array}$ & $\begin{array}{l}-0.18 \\
(0.04)\end{array}$ & $\begin{array}{c}0.29 \\
(0.00)\end{array}$ \\
\hline $\begin{array}{l}\text { Central bank } \\
\text { independence }\end{array}$ & $\begin{array}{l}-0.04 \\
(0.72)\end{array}$ & $\begin{array}{c}0.10 \\
(0.26)\end{array}$ & $\begin{array}{c}0.23 \\
(0.00)\end{array}$ & $\begin{array}{l}-0.25 \\
(0.14)\end{array}$ \\
\hline $\begin{array}{c}\text { Change in regulatory } \\
\text { index }\end{array}$ & $\begin{array}{l}-0.05 \\
(0.48)\end{array}$ & $\begin{array}{c}0.03 \\
(0.68)\end{array}$ & $\begin{array}{l}-0.08 \\
(0.24)\end{array}$ & $\begin{array}{c}0.09 \\
(0.12)\end{array}$ \\
\hline Fiscal stimulus & $\begin{array}{c}0.03 \\
(0.67)\end{array}$ & $\begin{array}{c}0.09 \\
(0.35)\end{array}$ & $\begin{array}{l}-0.17 \\
(0.11)\end{array}$ & $\begin{array}{l}-0.01 \\
(0.80)\end{array}$ \\
\hline $\begin{array}{l}\text { Exchange rate } \\
\text { depreciation }\end{array}$ & $\begin{array}{l}-\mathbf{0 . 1 3} \\
(\mathbf{0 . 0 0 )})\end{array}$ & $\begin{array}{c}0.07 \\
(0.37)\end{array}$ & $\begin{array}{c}0.26 \\
(0.00)\end{array}$ & $\begin{array}{c}0.06 \\
(0.23)\end{array}$ \\
\hline Output gap & $\begin{array}{l}-0.02 \\
(0.80)\end{array}$ & $\begin{array}{l}-0.38 \\
(0.00)\end{array}$ & $\begin{array}{c}\text { 0.16 } \\
(0.03)\end{array}$ & $\begin{array}{l}-0.12 \\
(0.12)\end{array}$ \\
\hline Transfers \& subsidies & $\begin{array}{l}-0.01 \\
(0.93)\end{array}$ & $\begin{array}{l}-0.19 \\
(0.01)\end{array}$ & $\begin{array}{l}-0.17 \\
(0.04)\end{array}$ & $\begin{array}{l}-0.42 \\
(0.00)\end{array}$ \\
\hline $\begin{array}{c}\text { State-directed } \\
\text { investment }\end{array}$ & $\begin{array}{c}0.07 \\
(0.56)\end{array}$ & $\begin{array}{c}0.15 \\
(0.11)\end{array}$ & $\begin{array}{l}-0.11 \\
(0.11)\end{array}$ & $\begin{array}{c}0.26 \\
(0.16)\end{array}$ \\
\hline $\begin{array}{c}\text { Politically } \\
\text { connected firms }\end{array}$ & $\begin{array}{l}-0.05 \\
(0.56)\end{array}$ & $\begin{array}{l}-0.09 \\
(0.17)\end{array}$ & $\begin{array}{l}-0.03 \\
(0.62)\end{array}$ & $\begin{array}{l}-0.02 \\
(0.92)\end{array}$ \\
\hline $\begin{array}{l}\text { State-controlled } \\
\text { firms }\end{array}$ & $\begin{array}{l}-0.03 \\
(0.71)\end{array}$ & $\begin{array}{c}0.04 \\
(0.68)\end{array}$ & $\begin{array}{l}-0.05 \\
(0.52)\end{array}$ & $\begin{array}{c}0.40 \\
(0.00)\end{array}$ \\
\hline
\end{tabular}


Panel B. Bank-level variables

\begin{tabular}{|c|c|c|c|c|}
\hline & Growth in lending & $\begin{array}{l}\text { Money } \\
\text { growth }\end{array}$ & $\begin{array}{c}\text { State } \\
\text { Run }\end{array}$ & $\begin{array}{c}\text { Bank } \\
\text { size }\end{array}$ \\
\hline Money growth & $\begin{array}{c}\text { 0.07 } \\
(\mathbf{0 . 0 5})\end{array}$ & & & \\
\hline $\begin{array}{c}\text { State run bank } \\
\text { indicator }\end{array}$ & $\begin{array}{c}0.04 \\
(0.37)\end{array}$ & $\begin{array}{c}013 \\
(0.00)\end{array}$ & & \\
\hline Bank size & $\begin{array}{l}-0.08 \\
(0.02)\end{array}$ & $\begin{array}{l}-0.05 \\
(0.16)\end{array}$ & $\begin{array}{l}-0.20 \\
(0.00)\end{array}$ & \\
\hline Bank liquidity & $\begin{array}{c}0.24 \\
(0.00)\end{array}$ & $\begin{array}{c}0.26 \\
(0.00)\end{array}$ & $\begin{array}{c}0.36 \\
(0.00)\end{array}$ & $\begin{array}{l}-0.19 \\
(0.00)\end{array}$ \\
\hline
\end{tabular}




\section{Table IV. Baseline regression results}

Economy-level panel is 2001 to 2010 spanning 40 economies for lending growth and 30 for capital spending growth, as listed in Table 2. Bank-level panel is 2001 to 2010 spanning 288 large banks in those economies. , as listed in Table 2. Money growth rate is change in monetary base over beginning of period monetary base, measured over the prior 12 months. Variables are as in Table 1 . Numbers in parentheses are p-values with coefficients significant at $10 \%$ or better in boldface, using economy-level clustering, euro-zone economies considered one cluster after the introduction of the euro.

\begin{tabular}{|c|c|c|c|c|c|c|c|c|}
\hline $\begin{array}{l}\text { Aggregation level } \\
\text { Explained variable: } \\
\text { growth in } \\
\text { Regression }\end{array}$ & $\begin{array}{l}\text { economy } \\
\text { lending } \\
4.1\end{array}$ & $\begin{array}{c}\text { economy } \\
\text { capital } \\
\text { spending } \\
4.2 \\
\end{array}$ & $\begin{array}{l}\text { bank } \\
\text { lending } \\
4.3\end{array}$ & $\begin{array}{l}\text { bank } \\
\text { lending } \\
4.4\end{array}$ & $\begin{array}{c}\text { bank } \\
\text { lending } \\
4.5\end{array}$ & $\begin{array}{c}\text { bank } \\
\text { lending } \\
4.6\end{array}$ & $\begin{array}{c}\text { bank } \\
\text { lending } \\
4.7\end{array}$ & $\begin{array}{c}\text { bank } \\
\text { lending } \\
4.8\end{array}$ \\
\hline Money growth & $\begin{array}{l}-0.06 \\
(0.23)\end{array}$ & $\begin{array}{l}-0.27 \\
(0.00)\end{array}$ & $\begin{array}{r}-0.16 \\
(0.01)\end{array}$ & $\begin{array}{l}-0.04 \\
(0.55)\end{array}$ & & $\begin{array}{c}0.03 \\
(0.93)\end{array}$ & $\begin{array}{c}0.02 \\
(0.95)\end{array}$ & \\
\hline $\begin{array}{l}\text { Fraction of banking system } \\
\text { state-run } x \text { money growth }\end{array}$ & $\begin{array}{c}0.23 \\
(0.06)\end{array}$ & $\begin{array}{c}0.79 \\
(\mathbf{0 . 0 0})\end{array}$ & & & & & & \\
\hline $\begin{array}{c}\text { State-run bank indicator } \\
x \text { money growth }\end{array}$ & & & $\begin{array}{c}\mathbf{0 . 3 0} \\
(\mathbf{0 . 0 0})\end{array}$ & $\begin{array}{c}0.22 \\
(0.01)\end{array}$ & $\begin{array}{c}0.20 \\
(\mathbf{0 . 0 4})\end{array}$ & $\begin{array}{c}0.32 \\
(\mathbf{0 . 0 0})\end{array}$ & $\begin{array}{l}0.25 \\
(0.00)\end{array}$ & $\begin{array}{l}0.26 \\
(0.01)\end{array}$ \\
\hline $\begin{array}{c}\text { Fraction of banking system } \\
\text { state-run }\end{array}$ & $\begin{array}{c}0.02 \\
(0.32)\end{array}$ & $\begin{array}{c}0.16 \\
(\mathbf{0 . 0 4})\end{array}$ & & & & & & \\
\hline State-run bank indicator & & & $\begin{array}{l}-0.01 \\
(0.68)\end{array}$ & $\begin{array}{l}-0.00 \\
(0.93)\end{array}$ & $\begin{array}{l}-0.00 \\
(1.00)\end{array}$ & $\begin{array}{l}-0.01 \\
(0.77)\end{array}$ & $\begin{array}{l}-0.01 \\
(0.81)\end{array}$ & $\begin{array}{c}0.00 \\
(0.98)\end{array}$ \\
\hline $\begin{array}{c}\text { Bank size } x \\
\text { money growth }\end{array}$ & & & & & & $\begin{array}{l}-0.03 \\
(0.39)\end{array}$ & $\begin{array}{l}-0.01 \\
(0.73)\end{array}$ & $\begin{array}{l}-0.01 \\
(0.51)\end{array}$ \\
\hline $\begin{array}{l}\text { Bank liquidity } x \\
\text { money growth }\end{array}$ & & & & & & $\begin{array}{c}0.36 \\
(0.38)\end{array}$ & $\begin{array}{l}-0.02 \\
(0.96)\end{array}$ & $\begin{array}{l}-0.34 \\
(0.34)\end{array}$ \\
\hline Bank size & & & & & & $\begin{array}{l}-0.00 \\
(0.82)\end{array}$ & $\begin{array}{l}-0.03 \\
(0.32)\end{array}$ & $\begin{array}{l}-0.01 \\
(0.69)\end{array}$ \\
\hline Bank liquidity & & & & & & $\begin{array}{c}0.10 \\
(0.23)\end{array}$ & $\begin{array}{c}0.07 \\
(0.39)\end{array}$ & $\begin{array}{c}0.08 \\
(0.36)\end{array}$ \\
\hline Fixed-effects & economy & economy & bank & $\begin{array}{l}\text { bank \& } \\
\text { year }\end{array}$ & $\begin{array}{l}\text { bank \& } \\
\text { economy } \\
\otimes \text { year }\end{array}$ & bank & $\begin{array}{l}\text { bank \& } \\
\text { year }\end{array}$ & $\begin{array}{c}\text { bank \& } \\
\text { economy } \\
\otimes \text { year }\end{array}$ \\
\hline Adjusted $R^{2}$ & 0.23 & 0.21 & 0.21 & 0.30 & 0.49 & 0.25 & 0.33 & 0.50 \\
\hline Observations & 246 & 183 & 1,261 & 1,261 & 1,261 & 1098 & 1,098 & 1,098 \\
\hline
\end{tabular}




\section{Table V: Interest rate drops rather than money growth}

Re-estimation of Table 4 regressions using interest rate drops to measure monetary policy. Interest rate drop is drop over the prior 12 months in key policy interest rate or benchmark interest rate if no key policy rate exists. Economylevel panel and bank-level panels are as in Table 4. Money growth rate is change in monetary base over beginning of period monetary base, measured over the prior 12 months. Variables are as in Table 1. Numbers in parentheses are p-values with coefficients significant at $10 \%$ or better in boldface, using economy-level clustering, euro-zone economies considered one cluster after the introduction of the euro.

\begin{tabular}{|c|c|c|c|c|c|c|c|c|}
\hline $\begin{array}{c}\text { Sample } \\
\text { Aggregation level } \\
\text { Explained variable: } \\
\text { growth in } \\
\text { Regression } \\
\end{array}$ & $\begin{array}{c}\text { all } \\
\text { economy } \\
\text { lending } \\
\mathbf{5 . 1}\end{array}$ & $\begin{array}{c}\text { all } \\
\text { economy } \\
\text { capital } \\
\text { spending } \\
5.2\end{array}$ & $\begin{array}{c}\text { all } \\
\text { bank } \\
\text { lending } \\
\mathbf{5 . 3}\end{array}$ & $\begin{array}{c}\text { all } \\
\text { bank } \\
\text { lending } \\
\mathbf{5 . 4}\end{array}$ & $\begin{array}{c}\text { all } \\
\text { bank } \\
\text { lending } \\
\mathbf{5 . 5}\end{array}$ & $\begin{array}{c}\text { all } \\
\text { bank } \\
\text { lending } \\
\mathbf{5 . 6}\end{array}$ & $\begin{array}{c}\text { all } \\
\text { bank } \\
\text { lending } \\
\mathbf{5 . 7}\end{array}$ & $\begin{array}{c}\text { all } \\
\text { bank } \\
\text { lending } \\
\mathbf{5 . 8}\end{array}$ \\
\hline Interest rate drop & $\begin{array}{l}-0.44 \\
(0.21)\end{array}$ & $\begin{array}{l}-0.59 \\
(0.36)\end{array}$ & $\begin{array}{l}-1.01 \\
(0.03)\end{array}$ & $\begin{array}{c}0.04 \\
(0.91)\end{array}$ & & $\begin{array}{l}-1.67 \\
(0.38)\end{array}$ & $\begin{array}{l}-0.66 \\
(0.74)\end{array}$ & \\
\hline $\begin{array}{c}\text { Fraction of banking } \\
\text { system state-run } x \text { interest } \\
\text { rate drop }\end{array}$ & $\begin{array}{c}1.40 \\
(0.09)\end{array}$ & $\begin{array}{c}3.41 \\
(0.06)\end{array}$ & & & & & & \\
\hline $\begin{array}{c}\text { State-run bank indicator } x \\
\text { money growth }\end{array}$ & & & $\begin{array}{c}1.74 \\
(0.01)\end{array}$ & $\begin{array}{c}1.30 \\
(\mathbf{0 . 0 1})\end{array}$ & $\begin{array}{c}0.92 \\
(0.09)\end{array}$ & $\begin{array}{c}1.42 \\
(\mathbf{0 . 0 1})\end{array}$ & $\begin{array}{c}1.33 \\
(\mathbf{0 . 0 1})\end{array}$ & $\begin{array}{c}0.96 \\
(0.10)\end{array}$ \\
\hline $\begin{array}{l}\text { Fraction of banking } \\
\text { system state-run }\end{array}$ & $\begin{array}{l}-0.04 \\
(0.36)\end{array}$ & $\begin{array}{c}0.17 \\
(0.01)\end{array}$ & & & & & & \\
\hline State-run bank indicator & & & $\begin{array}{c}0.03 \\
(0.27)\end{array}$ & $\begin{array}{c}0.03 \\
(0.21)\end{array}$ & $\begin{array}{c}0.03 \\
(0.39)\end{array}$ & $\begin{array}{c}0.02 \\
(0.40)\end{array}$ & $\begin{array}{c}0.02 \\
(0.44)\end{array}$ & $\begin{array}{c}0.03 \\
(0.45)\end{array}$ \\
\hline $\begin{array}{c}\text { Bank size } x \\
\text { money growth }\end{array}$ & & & & & & $\begin{array}{l}-0.02 \\
(0.89)\end{array}$ & $\begin{array}{c}0.02 \\
(0.93)\end{array}$ & $\begin{array}{c}0.08 \\
(0.63)\end{array}$ \\
\hline $\begin{array}{l}\text { Bank liquidity } x \\
\text { money growth }\end{array}$ & & & & & & $\begin{array}{c}4.82 \\
(0.03)\end{array}$ & $\begin{array}{l}2.35 \\
(0.32)\end{array}$ & $\begin{array}{l}-0.57 \\
(0.85)\end{array}$ \\
\hline Bank size & & & & & & $\begin{array}{l}-0.03 \\
(0.19)\end{array}$ & $\begin{array}{l}-0.04 \\
(0.32)\end{array}$ & $\begin{array}{l}-0.02 \\
(0.71)\end{array}$ \\
\hline Bank liquidity & & & & & & $\begin{array}{c}0.06 \\
(0.37)\end{array}$ & $\begin{array}{c}0.01 \\
(0.87)\end{array}$ & $\begin{array}{l}-0.04 \\
(0.49)\end{array}$ \\
\hline Fixed-effects & economy & economy & bank & $\begin{array}{c}\text { bank \& } \\
\text { year }\end{array}$ & $\begin{array}{c}\text { bank \& } \\
\text { economy } \\
\otimes \text { year }\end{array}$ & & $\begin{array}{l}\text { bank \& } \\
\text { year }\end{array}$ & $\begin{array}{c}\text { bank \& } \\
\text { economy } \\
\otimes \text { year }\end{array}$ \\
\hline Adjusted $R^{2}$ & 0.21 & 0.16 & 0.23 & 0.31 & 0.51 & 0.27 & 0.34 & 0.52 \\
\hline Observations & 238 & 167 & 1125 & 1125 & 1125 & 992 & 992 & 992 \\
\hline
\end{tabular}


Table VI. Fiscal and exchange rate policy, business cycle sensitivity, and banking regulations

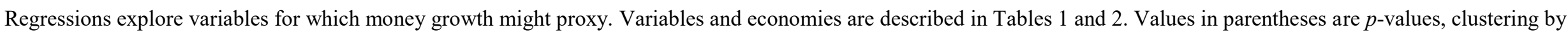
economy, with Eurozone economies one cluster after the euro introduction. Bold indicates significance at $10 \%$ or better.

\begin{tabular}{|c|c|c|c|c|c|c|c|c|c|c|c|c|c|c|c|c|}
\hline $\begin{array}{l}\text { Aggregation level } \\
\text { Explained variable: } \\
\text { growth in } \\
\text { Regression } \\
\end{array}$ & $\begin{array}{r}\text { Eco } \\
\text { lending } \\
6.1 \\
\end{array}$ & $\begin{array}{l}\text { nomy } \\
\text { capital } \\
\text { spending } \\
6.2 \\
\end{array}$ & $\begin{array}{c}\text { lending } \\
6.3\end{array}$ & $\begin{array}{c}\text { lending } \\
6.4 \\
\end{array}$ & \multicolumn{2}{|c|}{$\begin{array}{l}\text { economy } \\
\text { capital }\end{array}$} & $\begin{array}{c}\text { lending } \\
6.7 \\
\end{array}$ & $\begin{array}{c}\text { lending } \\
6.8 \\
\end{array}$ & \multicolumn{2}{|c|}{$\begin{array}{r}\text { economy } \\
\text { capital }\end{array}$} & $\begin{array}{c}\text { lending } \\
6.11 \\
\end{array}$ & $\begin{array}{c}\text { lending } \\
6.12 \\
\end{array}$ & $\begin{array}{c}\text { lending } \\
6.13\end{array}$ & $\begin{array}{l}\text { lomy } \\
\text { capital } \\
\text { spending } \\
6.14\end{array}$ & $\begin{array}{c}\text { lending } \\
6.15\end{array}$ & $\begin{array}{c}\text { lending } \\
6.16 \\
\end{array}$ \\
\hline Money growth & $\begin{array}{l}-0.07 \\
(0.12)\end{array}$ & $\begin{array}{l}-0.24 \\
(0.00)\end{array}$ & $\begin{array}{c}0.00 \\
(0.99)\end{array}$ & & $\begin{array}{l}-0.04 \\
(0.44)\end{array}$ & $\begin{array}{l}-0.20 \\
(0.00)\end{array}$ & $\begin{array}{l}-0.02 \\
(0.95)\end{array}$ & & $\begin{array}{l}-0.05 \\
(0.24)\end{array}$ & $\begin{array}{l}-0.11 \\
(0.01)\end{array}$ & $\begin{array}{c}0.05 \\
(0.90)\end{array}$ & & $\begin{array}{l}-0.06 \\
(0.21)\end{array}$ & $\begin{array}{l}-0.29 \\
(0.00)\end{array}$ & $\begin{array}{l}-1.12 \\
(0.73)\end{array}$ & \\
\hline $\begin{array}{c}\text { State-run }^{a} x \\
\text { money growth }\end{array}$ & $\begin{array}{c}0.33 \\
(0.00)\end{array}$ & $\begin{array}{c}0.86 \\
(0.00)\end{array}$ & $\begin{array}{c}0.25 \\
(0.00)\end{array}$ & $\begin{array}{c}0.22 \\
(0.03)\end{array}$ & $\begin{array}{c}0.22 \\
(0.10)\end{array}$ & $\begin{array}{c}0.63 \\
(0.00)\end{array}$ & $\begin{array}{c}0.25 \\
(0.00)\end{array}$ & $\begin{array}{c}0.27 \\
(\mathbf{0 . 0 0})\end{array}$ & $\begin{array}{c}0.22 \\
(0.01)\end{array}$ & $\begin{array}{c}0.63 \\
(0.00)\end{array}$ & $\begin{array}{c}0.23 \\
(0.00)\end{array}$ & $\begin{array}{c}0.26 \\
(0.01)\end{array}$ & $\begin{array}{c}0.23 \\
(0.08)\end{array}$ & $\begin{array}{c}0.99 \\
(0.00)\end{array}$ & $\begin{array}{c}0.23 \\
(0.00)\end{array}$ & $\begin{array}{c}0.25 \\
(0.05)\end{array}$ \\
\hline $\begin{array}{c}\text { Bank size } x \\
\text { money growth }\end{array}$ & & & $\begin{array}{c}0.00 \\
(0.89)\end{array}$ & $\begin{array}{l}-0.01 \\
(0.60)\end{array}$ & & & $\begin{array}{l}-0.01 \\
(0.84)\end{array}$ & $\begin{array}{l}-0.02 \\
(0.31)\end{array}$ & & & $\begin{array}{r}-0.01 \\
(0.7)\end{array}$ & $\begin{array}{l}-0.01 \\
(0.51)\end{array}$ & & & $\begin{array}{c}0.00 \\
(0.94)\end{array}$ & $\begin{array}{l}-0.02 \\
(0.39)\end{array}$ \\
\hline $\begin{array}{c}\text { Bank liquidity } x \\
\text { money growth }\end{array}$ & & & $\begin{array}{l}-0.05 \\
(0.91)\end{array}$ & $\begin{array}{l}-0.47 \\
(0.2)\end{array}$ & & & $\begin{array}{c}0.01 \\
(0.97)\end{array}$ & $\begin{array}{l}-0.37 \\
(0.28)\end{array}$ & & & $\begin{array}{l}-0.07 \\
(0.87)\end{array}$ & $\begin{array}{l}-0.34 \\
(0.35)\end{array}$ & & & $\begin{array}{c}0.30 \\
(0.45)\end{array}$ & $\begin{array}{l}-0.21 \\
(0.54)\end{array}$ \\
\hline State-run ${ }^{a}$ & $\begin{array}{c}0.02 \\
(0.38)\end{array}$ & $\begin{array}{c}0.16 \\
(0.01)\end{array}$ & $\begin{array}{l}-0.05 \\
(0.12)\end{array}$ & $\begin{array}{l}-0.04 \\
(0.55)\end{array}$ & $\begin{array}{c}0.03 \\
(0.24)\end{array}$ & $\begin{array}{c}0.17 \\
(0.01)\end{array}$ & $\begin{array}{l}-0.01 \\
(0.80)\end{array}$ & $\begin{array}{c}0.00 \\
(1.00)\end{array}$ & $\begin{array}{c}0.03 \\
(0.29)\end{array}$ & $\begin{array}{c}0.24 \\
(0.00)\end{array}$ & $\begin{array}{c}0.00 \\
(0.99)\end{array}$ & $\begin{array}{c}0.00 \\
(0.97)\end{array}$ & $\begin{array}{c}0.02 \\
(0.41)\end{array}$ & $\begin{array}{c}0.08 \\
(0.10)\end{array}$ & $\begin{array}{c}0.00 \\
(0.94)\end{array}$ & $\begin{array}{l}-0.01 \\
(0.89)\end{array}$ \\
\hline Bank liquidity & & & $\begin{array}{c}0.12 \\
(0.14)\end{array}$ & $\begin{array}{c}0.09 \\
(0.41)\end{array}$ & & & $\begin{array}{c}0.07 \\
(0.39)\end{array}$ & $\begin{array}{c}0.09 \\
(0.33)\end{array}$ & & & $\begin{array}{c}0.06 \\
(0.44)\end{array}$ & $\begin{array}{c}0.08 \\
(0.36)\end{array}$ & & & $\begin{array}{c}0.02 \\
(0.84)\end{array}$ & $\begin{array}{c}0.04 \\
(0.63)\end{array}$ \\
\hline Additional control: & & fiscal sti & imulus & & exch & hange rate & depreciat & tion & & output & tgap & & change & in capital & regulato & ry index \\
\hline $\begin{array}{c}\text { State-run }^{a} x \\
\text { additional control }\end{array}$ & $\begin{array}{c}0.81 \\
(0.56)\end{array}$ & $\begin{array}{l}2.70 \\
(0.14)\end{array}$ & $\begin{array}{c}0.62 \\
(0.51)\end{array}$ & $\begin{array}{c}0.06 \\
(0.92)\end{array}$ & $\begin{array}{c}0.10 \\
(0.06)\end{array}$ & $\begin{array}{c}0.19 \\
(0.06)\end{array}$ & $\begin{array}{l}-0.03 \\
(0.19)\end{array}$ & $\begin{array}{l}-0.04 \\
(0.08)\end{array}$ & $\begin{array}{c}0.98 \\
(0.11)\end{array}$ & $\begin{array}{c}1.18 \\
(0.02)\end{array}$ & $\begin{array}{c}0.42 \\
(0.40)\end{array}$ & $\begin{array}{c}0.04 \\
(0.94)\end{array}$ & $\begin{array}{l}-0.00 \\
(0.90)\end{array}$ & $\begin{array}{c}0.06 \\
(0.11)\end{array}$ & $\begin{array}{l}-0.01 \\
(0.89)\end{array}$ & $\begin{array}{c}-0.58 \\
(0.03)\end{array}$ \\
\hline $\begin{array}{c}\text { Additional } \\
\text { control }\end{array}$ & $\begin{array}{l}-0.05 \\
(0.90)\end{array}$ & $\begin{array}{c}0.06 \\
(0.89)\end{array}$ & $\begin{array}{l}-0.12 \\
(0.75)\end{array}$ & & $\begin{array}{l}-0.09 \\
(0.01)\end{array}$ & $\begin{array}{l}-0.10 \\
(0.12)\end{array}$ & $\begin{array}{l}-0.03 \\
(0.35)\end{array}$ & & $\begin{array}{l}-0.28 \\
(0.35)\end{array}$ & $\begin{array}{l}-1.67 \\
(0.00)\end{array}$ & $\begin{array}{c}0.14 \\
(0.75)\end{array}$ & & $\begin{array}{l}-0.00 \\
(0.84)\end{array}$ & $\begin{array}{l}-0.01 \\
(0.23)\end{array}$ & $\begin{array}{c}0.00 \\
(1.00)\end{array}$ & \\
\hline Fixed effects & economy & economy & $\begin{array}{c}\text { bank \& } \\
\text { year }\end{array}$ & $\begin{array}{c}\text { bank \& } \\
\text { economy } \\
\otimes \text { year }\end{array}$ & economy & economy & $\begin{array}{c}\text { bank \& } \\
\text { year }\end{array}$ & $\begin{array}{c}\text { bank \& } \\
\text { economy } \\
\otimes \text { year }\end{array}$ & economy & economy & $\begin{array}{c}\text { bank \& } \\
\text { year }\end{array}$ & $\begin{array}{c}\text { bank \& } \\
\text { economy } \\
\otimes \text { year }\end{array}$ & economy & economy & $\begin{array}{c}\text { bank \& } \\
\text { year }\end{array}$ & $\begin{array}{c}\text { bank \& } \\
\text { economy } \\
\otimes \text { year }\end{array}$ \\
\hline Adjusted $R^{2}$ & 0.23 & 0.22 & 0.34 & 0.50 & 0.25 & 0.21 & 0.34 & 0.50 & 0.25 & 0.35 & 0.33 & 0.50 & 0.09 & 0.22 & 0.34 & 0.50 \\
\hline Observations & 246 & 182 & 954 & 954 & 246 & 188 & 1,072 & 1,072 & 246 & 188 & 1,098 & 1,098 & 223 & 172 & 1,029 & 1,029 \\
\hline
\end{tabular}

a. State-run is the fraction of banking system state-run in economy-level regressions and state-run bank indicator in bank-level regressions 
Table VII. Baseline regressions adapted to consider the reach of the state

Regressions explore how measures of the reach of the state modulate difference between state-run and private-sector banks. Tables 1 and 2 , respectively, describe variables and economies. $P$-levels in parentheses cluster by economy, with Eurozone economies one cluster after the euro introduction. Bold indicates significance at $10 \%$ or better.

\begin{tabular}{|c|c|c|c|c|c|c|c|c|c|c|c|c|c|c|c|c|}
\hline \multirow{2}{*}{$\begin{array}{c}\text { Aggregation level } \\
\text { Explained variable: } \\
\text { growth in } \\
\text { Regression } \\
\end{array}$} & \multicolumn{2}{|c|}{ economy } & \multicolumn{2}{|c|}{ bank } & \multicolumn{2}{|c|}{ economy } & \multicolumn{2}{|c|}{ bank } & \multicolumn{2}{|c|}{ economy } & \multicolumn{2}{|c|}{ bank } & \multicolumn{2}{|c|}{ economy } & \multicolumn{2}{|c|}{ bank } \\
\hline & $\begin{array}{c}\text { lending } \\
7.1\end{array}$ & $\begin{array}{l}\text { capital } \\
\text { spend. } \\
7.2\end{array}$ & $\begin{array}{c}\text { lending } \\
7.3\end{array}$ & $\begin{array}{c}\text { lending } \\
7.4\end{array}$ & $\begin{array}{c}\text { lending } \\
7.5\end{array}$ & $\begin{array}{l}\text { capital } \\
\text { spend. } \\
7.6\end{array}$ & $\begin{array}{c}\text { lending } \\
7.7\end{array}$ & $\begin{array}{c}\text { lending } \\
7.8\end{array}$ & $\begin{array}{c}\text { lending } \\
7.9\end{array}$ & $\begin{array}{l}\text { capital } \\
\text { spend. } \\
7.10\end{array}$ & $\begin{array}{c}\text { lending } \\
7.11\end{array}$ & $\begin{array}{c}\text { lending } \\
7.12\end{array}$ & $\begin{array}{c}\text { lending } \\
7.13\end{array}$ & $\begin{array}{l}\text { capital } \\
\text { spend. } \\
7.14\end{array}$ & $\begin{array}{c}\text { lending } \\
7.15\end{array}$ & $\begin{array}{c}\text { lending } \\
7.16\end{array}$ \\
\hline Money growth & $\begin{array}{c}-0.06 \\
(-0.69)\end{array}$ & $\begin{array}{l}-0.17 \\
(0.44)\end{array}$ & $\begin{array}{l}-0.06 \\
(0.88)\end{array}$ & & $\begin{array}{l}-0.15 \\
(0.24)\end{array}$ & $\begin{array}{l}-0.05 \\
(0.70)\end{array}$ & $\begin{array}{c}0.10 \\
(0.81)\end{array}$ & & $\begin{array}{c}-0.09 \\
(0.0 .1)\end{array}$ & $\begin{array}{l}-0.26 \\
(0.00)\end{array}$ & $\begin{array}{l}0.15 \\
(0.72)\end{array}$ & & $\begin{array}{l}-0.08 \\
(0.20)\end{array}$ & $\begin{array}{l}-0.21 \\
(0.00)\end{array}$ & $\begin{array}{l}-0.06 \\
(0.87)\end{array}$ & \\
\hline $\begin{array}{c}\text { State-run }^{a} x \\
\text { money growth }\end{array}$ & $\begin{array}{c}0.27 \\
(0.29)\end{array}$ & $\begin{array}{c}0.94 \\
(0.07)\end{array}$ & $\begin{array}{c}0.29 \\
(0.10)\end{array}$ & $\begin{array}{c}0.31 \\
(0.14)\end{array}$ & $\begin{array}{c}0.55 \\
(0.00)\end{array}$ & $\begin{array}{c}0.31 \\
(0.27)\end{array}$ & $\begin{array}{c}0.33 \\
(0.01)\end{array}$ & $\begin{array}{c}0.33 \\
(\mathbf{0 . 0 3})\end{array}$ & $\begin{array}{c}0.44 \\
(0.00)\end{array}$ & $\begin{array}{l}0.60 \\
(0.00)\end{array}$ & $\begin{array}{c}0.28 \\
(0.00)\end{array}$ & $\begin{array}{c}0.17 \\
(\mathbf{0 . 0 8})\end{array}$ & $\begin{array}{c}0.29 \\
(0.08)\end{array}$ & $\begin{array}{c}0.55 \\
(0.09)\end{array}$ & $\begin{array}{c}0.39 \\
(0.00)\end{array}$ & $\begin{array}{c}0.27 \\
(0 . .07)\end{array}$ \\
\hline $\begin{array}{c}\text { Bank size } x \\
\text { money growth }\end{array}$ & & & $\begin{array}{l}-0.00 \\
(0.85)\end{array}$ & $\begin{array}{l}-0.01 \\
(0.69)\end{array}$ & & & $\begin{array}{l}-0.02 \\
(0.64)\end{array}$ & $\begin{array}{l}-0.01 \\
(0.71)\end{array}$ & & & $\begin{array}{l}-0.02 \\
(0.64)\end{array}$ & $\begin{array}{l}-0.00 \\
(0.87)\end{array}$ & & & $\begin{array}{c}0.01 \\
(0.85)\end{array}$ & $\begin{array}{c}0.02 \\
(0.47)\end{array}$ \\
\hline $\begin{array}{c}\text { Bank liquidity } x \\
\text { money growth }\end{array}$ & & & $\begin{array}{c}0.11 \\
(0.80)\end{array}$ & $\begin{array}{c}0.09 \\
(0.32)\end{array}$ & & & $\begin{array}{c}0.09 \\
(0.82)\end{array}$ & $\begin{array}{c}0.09 \\
(0.33)\end{array}$ & & & $\begin{array}{l}-0.29 \\
(0.45)\end{array}$ & $\begin{array}{c}0.12 \\
(0.29)\end{array}$ & & & $\begin{array}{l}-0.11 \\
(0.85)\end{array}$ & $\begin{array}{l}-0.54 \\
(0.44)\end{array}$ \\
\hline State-run ${ }^{a}$ & $\begin{array}{c}0.02 \\
(0.47)\end{array}$ & $\begin{array}{c}0.15 \\
(\mathbf{0 . 0 3})\end{array}$ & $\begin{array}{l}-0.01 \\
(0.80)\end{array}$ & $\begin{array}{l}-0.00 \\
(0.98)\end{array}$ & $\begin{array}{c}0.02 \\
(0.53)\end{array}$ & $\begin{array}{c}0.15 \\
(0.05)\end{array}$ & $\begin{array}{c}0.01 \\
(0.64)\end{array}$ & $\begin{array}{c}0.02 \\
(0.64)\end{array}$ & $\begin{array}{c}0.01 \\
(0.73)\end{array}$ & $\begin{array}{c}0.15 \\
(0.04)\end{array}$ & $\begin{array}{l}-0.06 \\
(0.11)\end{array}$ & $\begin{array}{l}-0.05 \\
(0.45)\end{array}$ & $\begin{array}{c}0.05 \\
(0.15)\end{array}$ & $\begin{array}{c}0.15 \\
(0.05)\end{array}$ & $\begin{array}{l}-0.01 \\
(0.44)\end{array}$ & $\begin{array}{c}0.01 \\
(0.37)\end{array}$ \\
\hline Bank size & & & $\begin{array}{l}-0.03 \\
(0.33)\end{array}$ & $\begin{array}{l}-0.02 \\
(0.29)\end{array}$ & & & $\begin{array}{l}-0.02 \\
(0.35)\end{array}$ & $\begin{array}{l}-0.02 \\
(0.36)\end{array}$ & & & $\begin{array}{l}-0.02 \\
(0.46)\end{array}$ & $\begin{array}{l}-0.02 \\
(0.28)\end{array}$ & & & $\begin{array}{l}-0.00 \\
(0.90)\end{array}$ & $\begin{array}{c}0.01 \\
(0.42)\end{array}$ \\
\hline Bank liquidity & & & $\begin{array}{c}0.08 \\
(0.80)\end{array}$ & $\begin{array}{l}-0.34 \\
(0.35)\end{array}$ & & & $\begin{array}{c}0.07 \\
(0.82)\end{array}$ & $\begin{array}{l}-0.33 \\
(0.36)\end{array}$ & & & $\begin{array}{c}\mathbf{0 . 1 8} \\
(\mathbf{0 . 0 3})\end{array}$ & $\begin{array}{l}-0.61 \\
(0.20)\end{array}$ & & & $\begin{array}{c}0.11 \\
(0.43)\end{array}$ & $\begin{array}{c}0.16 \\
(0.37)\end{array}$ \\
\hline Additional Control & & ansfers \& & subsidie & & & e-directed & d investm & ent & poli & tically-co & nnected $f$ & irms & & ate-contro & olled firm & \\
\hline $\begin{array}{c}\text { State-run }^{a} x \\
\text { additional control } x \\
\text { money growth }\end{array}$ & $\begin{array}{c}0.00 \\
(0.77)\end{array}$ & $\begin{array}{l}-0.02 \\
(0.56)\end{array}$ & $\begin{array}{l}-0.00 \\
(0.69)\end{array}$ & $\begin{array}{l}-0.00 \\
(0.73)\end{array}$ & $\begin{array}{l}-0.01 \\
(0.20)\end{array}$ & $\begin{array}{c}\mathbf{0 . 0 2} \\
(\mathbf{0 . 0 2})\end{array}$ & $\begin{array}{l}-0.00 \\
(0.36)\end{array}$ & $\begin{array}{l}-0.00 \\
(0.63)\end{array}$ & $\begin{array}{l}-0.01 \\
(0.50)\end{array}$ & $\begin{array}{c}0.01 \\
(0.37)\end{array}$ & $\begin{array}{l}-0.00 \\
(0.59)\end{array}$ & $\begin{array}{c}0.01 \\
(0.46)\end{array}$ & $\begin{array}{c}0.01 \\
(0.21)\end{array}$ & $\begin{array}{c}0.00 \\
(0.89)\end{array}$ & $\begin{array}{l}-0.01 \\
(0.33)\end{array}$ & $\begin{array}{c}0.00 \\
(0.84)\end{array}$ \\
\hline $\begin{array}{l}\text { Additional control } x \\
\text { money growth }\end{array}$ & $\begin{array}{c}0.00 \\
(0.87)\end{array}$ & $\begin{array}{l}-0.01 \\
(0.65)\end{array}$ & $\begin{array}{c}0.00 \\
(0.98)\end{array}$ & & $\begin{array}{c}0.00 \\
(0.65)\end{array}$ & $\begin{array}{l}-0.01 \\
(0.11)\end{array}$ & $\begin{array}{l}-0.00 \\
(0.77)\end{array}$ & & $\begin{array}{l}-0.00 \\
(0.97)\end{array}$ & $\begin{array}{c}0.00 \\
(0.65)\end{array}$ & $\begin{array}{c}0.00 \\
(0.63)\end{array}$ & & $\begin{array}{l}-0.00 \\
(0.92)\end{array}$ & $\begin{array}{l}-0.01 \\
(0.20)\end{array}$ & $\begin{array}{l}-0.01 \\
(0.06)\end{array}$ & \\
\hline Additional control & $\begin{array}{c}0.00 \\
(0.94)\end{array}$ & $\begin{array}{l}-0.00 \\
(0.93)\end{array}$ & $\begin{array}{l}-0.00 \\
(0.46)\end{array}$ & & $\begin{array}{c}0.00 \\
(0.84)\end{array}$ & $\begin{array}{c}0.00 \\
(0.96)\end{array}$ & $\begin{array}{c}0.00 \\
(0.06)\end{array}$ & & & & & & & & & \\
\hline Fixed-effects & economy & economy & $\begin{array}{c}\text { bank \& } \\
\text { year }\end{array}$ & $\begin{array}{c}\text { bank \& } \\
\text { economy } \\
\otimes \text { year }\end{array}$ & (O) & (Ot & $\begin{array}{c}\text { bank \& } \\
\text { year }\end{array}$ & $\begin{array}{c}\text { bank \& } \\
\text { economy } \\
\otimes \text { year }\end{array}$ & 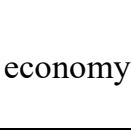 & conomy & $\begin{array}{c}\text { bank \& } \\
\text { year }\end{array}$ & $\begin{array}{c}\text { bank \& } \\
\text { economy } \\
\otimes \text { year }\end{array}$ & eccinon & 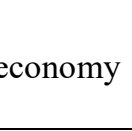 & $\begin{array}{c}\text { bank \& } \\
\text { year }\end{array}$ & $\begin{array}{c}\text { bank \& } \\
\text { economy } \\
\otimes \text { year }\end{array}$ \\
\hline Adjusted $R^{2}$ & 0.24 & 0.21 & 0.34 & 0.50 & 0.25 & 0.21 & 0.34 & 0.50 & 0.20 & 0.18 & 0.36 & 0.49 & 0.06 & 0.10 & 0.31 & 0.48 \\
\hline Observations & 232 & 183 & 1,072 & 1,072 & 230 & 180 & 1,056 & 1,056 & 215 & 172 & 913 & 913 & 172 & 150 & 733 & 733 \\
\hline
\end{tabular}

a. State-run is the fraction of banking system state-run in economy-level regressions and state-run bank indicator in bank-level regressions 


\section{Table VIII. The private sector only}

Economy-level regressions explaining aggregate lending to the private sector and capital spending by the private sector. Money growth rate is change in monetary base over beginning of period monetary base, measured over the prior 12 months. Variables are as in Table 1. Numbers in parentheses are p-values with coefficients significant at $10 \%$ or better in boldface, with economy-level clustering, Euro-zone countries considered one cluster after the introduction of the euro.

Explained variable: growth in

Regression
Money growth
Fraction of banking system state-run $x$ money growth

Fraction of banking system state-run

\section{Lending to} private sector

8.1

$-0.12$

(0.00)
Capital spending by private sector

8.2

$-0.21$

(0.00)

$\begin{array}{cc}0.17 & 0.52 \\ (0.08) & (0.00)\end{array}$

0.06 -0.00

(0.03) (0.98)

Fixed-effects

economy

economy

Adjusted $R^{2}$

0.26

0.21

Observations

246

184 


\section{Table IX. Central bank independence}

Money growth rate is change in monetary base over beginning of period monetary base, measured over the prior 12 months. Variables are as in Table 1, panel data is as in Table 4. Numbers in parentheses are p-values with coefficients significant at $10 \%$ or better in boldface, with economy-level clustering Euro-zone countries considered one cluster after the introduction of the euro.

Aggregation level

Explained variable: growth in

Regression
Money growth
State-run x money growth
Bank size $x$ money growth
Bank liquidity $x$ money growth

State-run

Bank size

Bank liquidity

State-run ${ }^{a} x$ central bank independence $x$ money growth

Central bank independence $x$ money growth

Fixed-effects

$$
\text { eco }
$$

lending

economy bank bank




\section{Table X. Bank privatizations}

Explained variable is bank-level loan growth, defined as the bank's year-on-year growth rate in real gross loans. Sample include observations within 1 year of the privatization year (exactly two observations per privatization: $t=$ $1,+1)$. The sample includes only banks with at least one observation both before and after the privatization year. Money growth is for the prior 12 months. Regression in column 3 is a stepwise regression, where additional control variables are included with forward selection at $10 \%$ probability. All regressions include bank fixed-effects and residuals are clustered by economy and Euro-zone countries considered one economy after introduction of the euro. Variables are defined in Table 1. Numbers in parentheses are p-values with coefficients significant at $10 \%$ or better in boldface.

\begin{tabular}{|c|c|c|c|}
\hline $\begin{array}{l}\text { Estimation method } \\
\text { Regression }\end{array}$ & $\begin{array}{l}\text { OLS } \\
\mathbf{1 0 . 1}\end{array}$ & $\begin{array}{l}\text { OLS } \\
\mathbf{1 0 . 2}\end{array}$ & $\begin{array}{c}\text { Stepwise } \\
\mathbf{1 0 . 3}\end{array}$ \\
\hline Money growth & $\begin{array}{c}0.67 \\
(0.02)\end{array}$ & $\begin{array}{c}1.43 \\
(0.54)\end{array}$ & $\begin{array}{c}\mathbf{0 . 6 4} \\
(\mathbf{0 . 0 0})\end{array}$ \\
\hline $\begin{array}{c}\text { After privatization dummy } x \\
\text { Money growth }\end{array}$ & $\begin{array}{l}-0.89 \\
(0.02)\end{array}$ & $\begin{array}{l}-1.06 \\
(0.00)\end{array}$ & $\begin{array}{l}-0.94 \\
(0.01)\end{array}$ \\
\hline Bank size $x$ Money growth & & $\begin{array}{l}-0.08 \\
(0.69)\end{array}$ & Drops \\
\hline Bank liquidity $x$ Money growth & & $\begin{array}{l}-0.23 \\
(0.92)\end{array}$ & Drops \\
\hline After privatization dummy & $\begin{array}{c}0.12 \\
(0.12)\end{array}$ & $\begin{array}{c}0.11 \\
(0.06)\end{array}$ & $\begin{array}{c}0.10 \\
(0.27)\end{array}$ \\
\hline Bank size & & $\begin{array}{l}-0.02 \\
(0.93)\end{array}$ & drops \\
\hline Bank liquidity & & $\begin{array}{l}-1.26 \\
(0.00)\end{array}$ & $\begin{array}{l}-1.28 \\
(0.00)\end{array}$ \\
\hline Fixed-effects & bank & bank & bank \\
\hline Adjusted $\mathrm{R}^{2}$ & 0.64 & 0.77 & 0.77 \\
\hline Number of Observations & 36 & 36 & 36 \\
\hline Number of Banks & 18 & 18 & 18 \\
\hline
\end{tabular}




\section{Table XI. Election cycles}

Economy-level sample is the 40 countries for lending growth and 30 countries for capital spending growth listed in Table 2. Bank-level sample is 288 large banks in those economies. Money growth rate is change in monetary base over beginning of period monetary base, measured over the prior 12 months. Definitions of election years and other variables are given in Table 1, panel data is as in Table 4. Variables are not winsorized. Residuals are clustered by economy, with the Euro-zone considered one economy after the introduction of the euro. Numbers in parentheses are p-values with coefficients significant at $10 \%$ or better in boldface.

\begin{tabular}{|c|c|c|c|c|}
\hline $\begin{array}{c}\text { Aggregation level } \\
\text { Explained variable: } \text { growth in } \\
\text { Regression }\end{array}$ & $\begin{array}{c}\text { economy } \\
\text { lending } \\
11.1\end{array}$ & $\begin{array}{l}\text { economy } \\
\text { capital } \\
\text { spending } \\
11.2\end{array}$ & $\begin{array}{c}\text { bank } \\
\text { lending } \\
\mathbf{1 1 . 3}\end{array}$ & $\begin{array}{c}\text { bank } \\
\text { lending } \\
\mathbf{1 1 . 4}\end{array}$ \\
\hline Money growth & $\begin{array}{c}0.01 \\
(0.87)\end{array}$ & $\begin{array}{l}-0.12 \\
(0.15)\end{array}$ & $\begin{array}{c}0.04 \\
(0.88)\end{array}$ & \\
\hline State-run ${ }^{a} x$ money growth & $\begin{array}{c}0.01 \\
(0.91)\end{array}$ & $\begin{array}{c}1.34 \\
(0.02)\end{array}$ & $\begin{array}{c}0.16 \\
(0.00)\end{array}$ & $\begin{array}{c}0.26 \\
(0.00)\end{array}$ \\
\hline Bank size $x$ money growth & & & $\begin{array}{l}-0.01 \\
(0.58)\end{array}$ & $\begin{array}{l}-0.03 \\
(0.14)\end{array}$ \\
\hline Bank liquidity $x$ money growth & & & $\begin{array}{l}-0.10 \\
(0.70)\end{array}$ & $\begin{array}{l}-0.54 \\
(0.19)\end{array}$ \\
\hline State-run & $\begin{array}{c}0.03 \\
(0.44)\end{array}$ & $\begin{array}{c}0.24 \\
(0.04)\end{array}$ & $\begin{array}{c}0.00 \\
(0.94)\end{array}$ & $\begin{array}{l}-0.00 \\
(1.00)\end{array}$ \\
\hline Bank size & & & $\begin{array}{l}-0.04 \\
(0.24)\end{array}$ & $\begin{array}{l}-0.02 \\
(0.60)\end{array}$ \\
\hline Bank liquidity & & & $\begin{array}{c}0.15 \\
(0.15)\end{array}$ & $\begin{array}{c}0.17 \\
(0.15)\end{array}$ \\
\hline $\begin{array}{c}\text { State-run }{ }^{a} x \text { Election year } \\
x \text { Money growth }\end{array}$ & $\begin{array}{c}0.36 \\
(0.04)\end{array}$ & $\begin{array}{c}0.58 \\
(0.02)\end{array}$ & $\begin{array}{c}0.13 \\
(0.53)\end{array}$ & $\begin{array}{c}0.27 \\
(\mathbf{0 . 0 7})\end{array}$ \\
\hline Election year $x$ money growth & $\begin{array}{l}-0.11 \\
(0.18)\end{array}$ & $\begin{array}{l}-0.12 \\
(0.09)\end{array}$ & $\begin{array}{c}0.02 \\
(0.79)\end{array}$ & \\
\hline Election year & $\begin{array}{c}0.01 \\
(0.63)\end{array}$ & $\begin{array}{c}0.00 \\
(0.80)\end{array}$ & & \\
\hline Fixed-effects & economy & economy & $\begin{array}{c}\text { bank \& } \\
\text { year }\end{array}$ & $\begin{array}{c}\text { bank \& } \\
\text { economy } \otimes \text { year }\end{array}$ \\
\hline Adjusted $R^{2}$ & 0.07 & 0.21 & 0.30 & 0.48 \\
\hline Observations & 239 & 183 & 1,063 & 1,063 \\
\hline
\end{tabular}

